\title{
Multi-year observations reveal a larger than expected autumn respiration signal across northeast Eurasia
}

Brendan Byrne ${ }^{1}$, Junjie Liu ${ }^{1,2}$, Yonghong Yi ${ }^{3,4}$, Abhishek Chatterjee ${ }^{1}$, Sourish Basu ${ }^{5,6}$, Rui Cheng ${ }^{2}$, Russell Doughty ${ }^{2,7}$, Frédéric Chevallier ${ }^{8}$, Kevin W. Bowman ${ }^{1,3}$, Nicholas C. Parazoo ${ }^{1}$, David Crisp ${ }^{1}$, Xing Li ${ }^{9}$, Jingfeng Xiao ${ }^{10}$, Stephen Sitch ${ }^{11}$, Bertrand Guenet ${ }^{12}$, Feng Deng ${ }^{13}$, Matthew S. Johnson ${ }^{14}$, Sajeev Philip ${ }^{15}$, Patrick C. McGuire ${ }^{16}$, and Charles E. Miller ${ }^{1}$

${ }^{1}$ Jet Propulsion Laboratory, California Institute of Technology, Pasadena, CA, USA

${ }^{2}$ Division of Geological and Planetary Sciences, California Institute of Technology, Pasadena, CA, USA

${ }^{3}$ Joint Institute for Regional Earth System Science and Engineering, University of California, Los Angeles, CA, USA

${ }^{4}$ College of Surveying and Geo-Informatics, Tongji University, China

${ }^{5}$ Global Modeling and Assimilation Office, NASA Goddard Space Flight Center, Greenbelt, MD, USA

${ }^{6}$ Earth System Science Interdisciplinary Center, University of Maryland, College Park, MD, USA

${ }^{7}$ College of Atmospheric and Geographic Sciences, University of Oklahoma, Norman, OK USA

${ }^{8}$ Laboratoire des Sciences du Climat et de l'Environnement/IPSL, CEA-CNRS-UVSQ, Université Paris-Saclay, 91191

Gif-sur-Yvette, France

${ }^{9}$ Research Institute of Agriculture and Life Sciences, Seoul National University, Seoul, South Korea

${ }^{10}$ Earth Systems Research Center, Institute for the Study of Earth, Oceans, and Space, University of New Hampshire, Durham, NH, USA

${ }^{11}$ College of Life and Environmental Sciences, University of Exeter, Exeter EX4 4RJ, UK

${ }^{12}$ Laboratoire de Géologie, Ecole Normale Supérieure/CNRS UMR8538, IPSL, PSL Research University, Paris, France

${ }^{13}$ Department of Physics, University of Toronto, Toronto, Ontario, Canada

${ }^{14}$ NASA Ames Research Center, Moffett Field, CA, USA

${ }^{15}$ Centre for Atmospheric Sciences, Indian Institute of Technology Delhi, New Delhi, India

${ }^{16}$ Department of Meteorology and National Centre for Atmospheric Science, University of Reading, Reading, UK

Correspondence: Brendan Byrne (brendan.k.byrne@jpl.nasa.gov)

\begin{abstract}
Site-level observations have shown pervasive cold season $\mathrm{CO}_{2}$ release across Arctic and boreal ecosystems, impacting annual carbon budgets. Still, the seasonality of $\mathrm{CO}_{2}$ emissions are poorly quantified across much of the high latitudes due to the sparse coverage of site-level observations. Space-based observations provide the opportunity to fill some observational

5 gaps for studying these high latitude ecosystems, particularly across poorly sampled regions of Eurasia. Here, we show that data-driven net ecosystem exchange (NEE) from atmospheric $\mathrm{CO}_{2}$ observations implies strong summer uptake followed by strong autumn release of $\mathrm{CO}_{2}$ over the entire cold northeastern region of Eurasia during the 2015-2019 study period. Combining data-driven NEE with satellite-based estimates of gross primary production (GPP), we show that this seasonality implies less summer heterotrophic respiration $\left(R_{h}\right)$ and greater autumn $R_{h}$ than would be expected given an exponential relationship between respiration and surface temperature. Furthermore, we show that this seasonality of NEE and $\mathrm{R}_{\mathrm{h}}$ over northeastern
\end{abstract}


https://doi.org/10.5194/bg-2022-40

Preprint. Discussion started: 2 March 2022

(c) Author(s) 2022. CC BY 4.0 License.

\section{(c) (i)}

Eurasia is not captured by the TRENDY v8 ensemble of dynamic global vegetation models (DGVMs), which estimate that only $52 \%$ of annual $R_{h}$ occurs during Aug-Apr, while the data-driven estimate suggests $64-70 \%$ of annual $R_{h}$ occurs over this period. We explain this seasonal shift in $\mathrm{R}_{\mathrm{h}}$ by respiration from soils at depth during the zero curtain period, when sub-surface soils remain unfrozen up to several months after the surface has frozen. Additional impacts of physical processes related to freeze-thaw dynamics may contribute to the seasonality of $R_{h}$. This study confirms a significant and spatially extensive early cold season $\mathrm{CO}_{2}$ efflux in the permafrost rich region of northeast Eurasia, and suggests that autumn $\mathrm{R}_{\mathrm{h}}$ from subsurface soils in the northern high latitudes is not well captured by current DGVMs.

Copyright statement. @ 2022 California Institute of Technology, government sponsorship acknowledged.

\section{Introduction}

Boreal and Arctic ecosystems hold vast quantities of soil carbon and play an important role in the global carbon cycle (Schuur et al., 2015). These ecosystems are also experiencing the most rapid climate change (Overland et al., 2018), driving major changes in the carbon cycle, including: greening trends (Park et al., 2016), permafrost thaw (Schuur et al., 2015; Turetsky et al., 2019, 2020), and increased fire frequency and intensity (Veraverbeke et al., 2017, 2021). Yet, the impact of these changes on the carbon budget of the region remains uncertain (Schuur et al., 2015; McGuire et al., 2018; Miner et al., 2022). In part, this is due to sparse site level observations in boreal and Arctic ecosystems, while the limited available observations of high latitude ecosystems are providing surprises.

A meta-analysis of Arctic and boreal site-level flux measurements from the literature found pervasive $\mathrm{CO}_{2}$ release during the cold season (Natali et al., 2019), such that the cold season is not a dormant period but strongly impacts annual carbon budgets (Zimov et al., 1993; Björkman et al., 2010; Natali et al., 2019). Particularly strong releases of $\mathrm{CO}_{2}$ have been observed during the early cold season (Commane et al., 2017; Mastepanov et al., 2013; Jeong et al., 2018). This has been linked to the "zero-curtain effect", wherein the air and surface temperatures drop below $0{ }^{\circ} \mathrm{C}$ but deeper soils remain unfrozen for an extended period due to latent heat release (Outcalt et al., 1990; Romanovsky and Osterkamp, 2000; Hinkel et al., 2001; Zona et al., 2016). The result is an "active layer" of unfrozen soil that can persist for months, resulting in greater respiration than would be expected based on air temperature. Both aircraft (Commane et al., 2017) and site-level (Mastepanov et al., 2013; Jeong et al., 2018) measurements have found substantial $\mathrm{CO}_{2}$ release during the zero-curtain period over Alaska (Sep-Dec) that is not well captured by our current generation of Earth System Models (Commane et al., 2017). Similarly, $\mathrm{CO}_{2}$ mole fractions enhancements within soils have been observed during the zero-curtain period (Wilkman et al., 2021; Raz-Yaseef et al., 2017). Mechanistically, both biological and physical processes likely contribute to the enhanced early cold season $\mathrm{CO}_{2}$ release. Physically, freezing forces dissolved $\mathrm{CO}_{2}$ out of solution (Bing et al., 2015), which may then be released through mechanical channels and fissures in the soil that form during freezing (Mastepanov et al., 2013; Pirk et al., 2015; Wilkman et al., 2021). Enhanced $\mathrm{CO}_{2}$ effluxes (release to the atmosphere) have also been observed during the spring thaw (Raz-Yaseef et al., 2017; Arndt et al., 2020). This spring signal has been linked to a delayed release of $\mathrm{CO}_{2}$ production from the previous early cold season (Raz-Yaseef et al., 2017), while a rapid warming and introduction of oxygen during snow melt has also been proposed as a contributor to this signal (Arndt et al., 2020). Finally, observed $\mathrm{CO}_{2}$ effluxes during the middle of the cold season 
https://doi.org/10.5194/bg-2022-40

Preprint. Discussion started: 2 March 2022

(c) Author(s) 2022. CC BY 4.0 License.

\section{(c) (i)}

(Natali et al., 2019) have been mechanistically linked to microbial respiration that persists at subzero bulk soil temperatures

(Rivkina et al., 2000; Panikov et al., 2006; McMahon et al., 2009; Drotz et al., 2010), with a possible additional contribution from the diffusion of stored $\mathrm{CO}_{2}$ that is produced during the non-frozen season (Natali et al., 2019).

Still, the full spatial extent and magnitude of cold season $\mathrm{CO}_{2}$ release is not well characterized due to sparsity of sitelevel observations, particularly over much of north Eurasia. Here, we employ a "top-down" approach to estimate the seasonal cycle of data-driven carbon fluxes using space-based observations during the period 2015-2019. This approach complements previous site-level analyses by providing $\mathrm{CO}_{2}$ flux constraints on large continental-scale regions. We utilize these data to investigate carbon cycle dynamics over three large regions within Eurasia (Fig. 1), which are defined based on the east-west temperature gradient (see Sec. 2.1), with the coldest region in the east and warmest region in the west. We further compare the observationally-constrained seasonality of $\mathrm{CO}_{2}$ fluxes to a suite of dynamic global vegetation models (DGVMs) from the TRENDY ensemble (Sitch et al., 2015) version 8 as used in the Global Carbon Budget 2019 (Friedlingstein et al., 2019) (Sec. 3.1). Our study addresses two main questions: (1) Do large-scale observational constraints support enhanced $\mathrm{CO}_{2}$ effluxes during the shoulder seasons at high-latitudes? And if so, (2) what are the underlying mechanisms driving this behaviour?

We first examine the seasonality of net ecosystem exchange (NEE) constrained by atmospheric inversions of retrieved column-averaged dry-air mole fractions of $\mathrm{CO}_{2}\left(\mathrm{X}_{\mathrm{CO}_{2}}\right)$ from the Orbiting Carbon Observatory 2 (OCO-2) (Crisp et al., 2017; Eldering et al., 2017) and by flask and in situ $\mathrm{CO}_{2}$ measurements (Sec. 2.2). Monthly NEE is obtained from version 9 of the OCO-2 Model Inter-comparison Project (OCO-2 MIPv9) (Peiro et al., 2021). In addition, we perform a set of three higher temporal resolution inversions using the CAMS, TM5-4DVar and CMS-Flux inversion systems to examine sub-monthly variability in $\mathrm{CO}_{2}$ fluxes.

We then look to decompose NEE into component fluxes to better understand the processes driving the seasonality of NEE. In particular, we decompose the data-driven NEE fluxes into net primary production (NPP) and heterotrophic respiration $\left(\mathrm{R}_{\mathrm{h}}\right)$ :

$\mathrm{NEE}=\mathrm{R}_{\mathrm{h}}-\mathrm{NPP}$.

To do this, we utilize four data-driven gross primary production (GPP) products: FLUXCOM (Jung et al., 2020), FluxSat (Joiner and Yoshida, 2020), the Vegetation Photosynthesis Model (VPM) (Zhang et al., 2017), and the Global OCO-2-based SIF product (GOSIF) (Li and Xiao, 2019). These datasets utilize MODIS reflectances, OCO-2 solar induced fluorescence and reanalysis data to infer GPP, and thus provide an ensemble of global estimates of GPP to inform its uncertainty. NPP is estimated from GPP using the carbon use efficiency (CUE) from the TRENDY models (Sec. 2.4) using the relationship:

$\mathrm{NPP}=\mathrm{CUE} \times \mathrm{GPP}$.

We then combine the data-driven estimates of NEE and NPP to recover a data-driven seasonal cycle of $R_{h}$ (Sec. 2.5).

We perform this analysis at two temporal resolutions. First, we leverage the large ensembles from TRENDY and the OCO-2 MIPv9 that provide fluxes at monthly temporal resolution (Sec. 3.1). However, because phenological changes can be significant on shorter timescales (e.g., weekly, Parazoo et al. (2018a)), we perform a second analysis at 14 day temporal resolution using 
https://doi.org/10.5194/bg-2022-40

Preprint. Discussion started: 2 March 2022

(c) Author(s) 2022. CC BY 4.0 License.
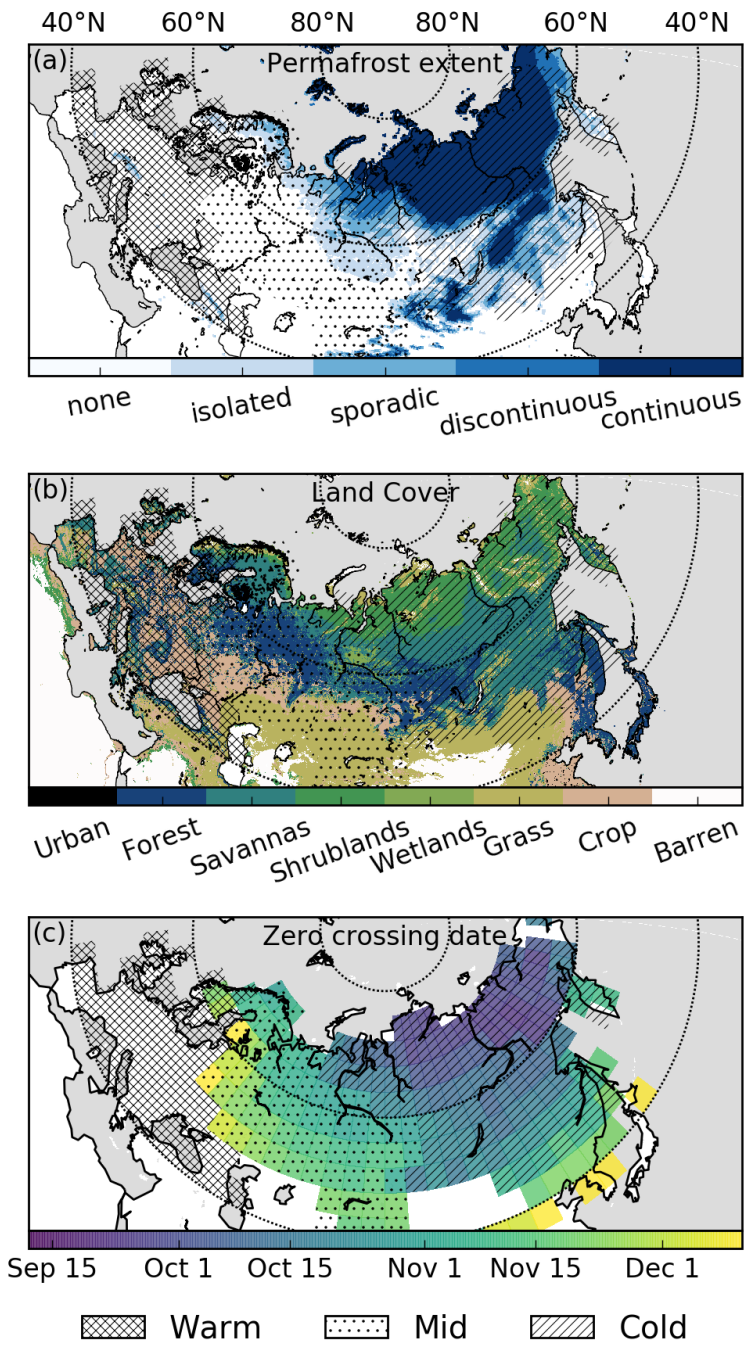

Figure 1. (a) Permafrost extent over 2000-2016 (Obu et al., 2019; Obu et al., 2018) (b) MODIS IGBP (MOD12C1 v6) land cover for urban areas, forest (tree cover $>60 \%$ and height $>2 \mathrm{~m}$ ), savanna (tree cover $10-60 \%$ and height $>2 \mathrm{~m}$ ), shrublands (woody perennials cover $>10 \%$ and height $<2 \mathrm{~m}$ ), grasslands, croplands, and barren land. (c) zero-crossing date (date when the mean soil temperature drops below $0{ }^{\circ} \mathrm{C}$ ) for the top $0.5 \mathrm{~m}$ of soil from the MERRA-2 Land dataset at $4^{\circ} \times 5^{\circ}$ spatial resolution. Gridcells with no shading do not have a zero-crossing date. Three regions are shown by different hatching patterns. The "Warm" (cross hatching) region does not have a zero-crossing date, the "Mid" (dots) region has a zero-crossing date after Oct 27, and the "Cold" (diagonal hatching) region has a zero-crossing date before Oct 27. Note that some adjustments from these definition are made so that the regions are contiguous. The Warm, Mid, and Cold regions have land areas of $5.66 \times 10^{6} \mathrm{~km}, 8.66 \times 10^{6} \mathrm{~km}$, and $12.65 \times 10^{6} \mathrm{~km}$, respectively.

three inversion analyses that optimize weekly or 14 day NEE fluxes (Sec. 3.2). For these 14 day fluxes, we further examine 
https://doi.org/10.5194/bg-2022-40

Preprint. Discussion started: 2 March 2022

(c) Author(s) 2022. CC BY 4.0 License.

(c) (i)

mechanistic explanations for data-model differences in $\mathrm{R}_{\mathrm{h}}$ using a range of models (Sec. 3.3). Finally, Sec. 4 provides a discussion of the results and Sec. 5 summarizes the conclusions.

\section{Data and methods}

\subsection{Environmental data and region definitions}

We utilize MERRA-2 Land soil temperature data (Reichle et al., 2011, 2017; Gelaro et al., 2017) to define three large regions within Eurasia (Fig. 1). These data were downloaded from the Goddard Earth Sciences Data and Information Services Center at monthly temporal resolution and $4^{\circ} \times 5^{\circ}$ spatial resolution (regridded from model horizontal resolution of $\sim 50 \mathrm{~km}$ ). Three regions are defined based on the date at which the top $0.5 \mathrm{~m}$ of MERRA-2 Land soil temperature falls below $0^{\circ} \mathrm{C}$, referred to as the "zero-crossing date", for a mean seasonal cycle averaged over four years (2015, 2016, 2018 and 2019). The "Cold" region has a zero-crossing date before Oct 27, the "Mid" region has a zero-crossing date after Oct 27, and the "Warm" region does not have a zero-crossing date. This date was chosen as a cutoff to create two similarly sized Mid and Cold regions. Some adjustments from these definitions are made so that the regions are contiguous. We aggregate the $\mathrm{CO}_{2}$ fluxes described below to these regions by (1) interpolating the Warm, Mid and Cold regions from $4^{\circ} \times 5^{\circ}$ spatial resolution to the grid of the $\mathrm{CO}_{2}$ flux datasets (both GPP and NEE), and (2) calculate the area weighted net fluxes over the regions. We also obtain the downward shortwave flux from the MERRA-2 Land dataset.

Several datasets are also used for supplementary evaluation of the MERRA-2 Land soil temperature seasonality (Text S2). For that analysis, we use ERA5-Land reanalysis soil temperature data (Munoz Sabater, 2019), generated using Copernicus Climate Change Service Information 2020. We also examined monthly soil temperature from seven models from the Coupled Model Intercomparison Project Phase 6 (CMIP6) (Eyring et al., 2016) for the historical and Shared Socioeconomic Pathway 585 (ssp585) simulations, which is the highest emission scenario. The CMIP6 simulations were included to compare with MERRA-2 simulated soil temperature over 2010-2019, and to examine possible trends in soil temperature under a high emission scenario. The model runs are: CanESM5 (r1i1p2f1), MIROC ES2L (r1i1p1f2), ACCESS EMS1 (r1i1p1f1), MRI ESM2 0 (historical r1i1p1f1, ssp585 r1i2p1f1), CNRM ESM2 1 (r1i1p1f2), E3SM 11 (r1i1p1f1), and UKESM1 0 LL (r4i1p1f2). These models were chosen because they participated in the Coupled Climate-Carbon Cycle Model Intercomparison ( $\left.\mathrm{C}_{4} \mathrm{MIP}\right)$ (Jones et al., 2016). Finally, we compare the MERRA-2 Land soil temperature to borehole soil temperature measurements over the period 1998-2020, which were downloaded from the Global Terrestrial Network for Permafrost (GTN-P) borehole database (http://gtnpdatabase.org/boreholes).

\subsection{Atmospheric flux inversions}

The OCO-2 Model Inter-comparison Project (OCO-2 MIP) provides standardized experimental set-ups for assimilating atmospheric $\mathrm{CO}_{2}$ to estimate net biosphere exchange (NBE), defined as

$\mathrm{NBE}=\mathrm{NEE}+\mathrm{BB}$, 
https://doi.org/10.5194/bg-2022-40

Preprint. Discussion started: 2 March 2022

(c) Author(s) 2022. CC BY 4.0 License.

where BB is biomass burning, across a range of inversion systems. Version 9 of the OCO-2 MIP (MIPv9, (Peiro et al., 2021)), provides ensembles of nine inversion systems that assimilated a standardized set of in situ and flask $\mathrm{CO}_{2}$ measurements for one experiment (referred to as "IS") and OCO-2 ACOS b9 land nadir and land glint retrievals for a second experiment (referred to as "LNLG"). We estimate NEE fluxes from MIPv9 NBE fluxes by removing biomass burning emissions from the Global Fire Emissions Database version 4 (GFED4.1s) (van der Werf et al., 2017). GFED4.1s provides estimates of biomass burning using MODIS burned area (Giglio et al., 2013), thermal anomalies, and surface reflectance observations (Randerson et al., 2012). Note that biomass burning is a relatively small contribution to NBE over the regions examined here during the study period (2015-2019) (Fig. S1). The NEE fluxes produced by each ensemble member over northern Eurasia are shown in Fig. S2.

To examine variability in fluxes at the sub-monthly time step, we examine three other inversion NEE estimates that optimize sub-monthly NEE fluxes: TM5-4DVAR ${ }_{14 \text { day }}$ LNLGIS, CAMS ${ }_{14 \text { day }}$ LNLGIS, and CMS-Flux $_{14 \text { day }}$ LNLGIS. These inversions assimilated both in situ and flask $\mathrm{CO}_{2}$ in addition to OCO-2 ACOS b10 land nadir and land glint retrievals (we refer to this experiment as LNLGIS). Note that the ACOS b10 retrievals are updated from the b9 retrievals employed in MIPv9. The prior and posterior NEE fluxes produced by each ensemble member are shown in Fig. S3, and the inversion set-ups are described below.

TM5-4DVAR is a variational inversion framework based on the TM5 atmospheric tracer transport model (Meirink et al.,

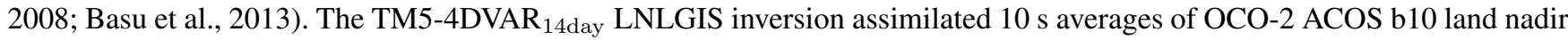
and land glint measurements concurrently with in situ measurements to optimize weekly NEE and ocean fluxes. The OCO-2 $10 \mathrm{~s}$ averages were constructed analogous to the b9 $10 \mathrm{~s}$ averages assimilated by models in MIPv9 (Peiro et al., 2021). The in situ measurements assimilated were updated from Peiro et al. (2021), specifically ObsPack NRT 5.0 was replaced by NRT 5.2. The flux inversion set-up was identical to the set-up of "TM5-4DVAR" in Peiro et al. (2021), except (i) the inversion was run from 2014-06-01 to 2021-02-01 (instead of 2014-09-01 to 2019-06-01 in Peiro et al. (2021)), (ii) ECMWF ERA5 meteorology was used to drive the model instead of ERA Interim, (iii) a $1^{\circ} \times 1^{\circ}$ transport grid over North America was nested inside the global $3^{\circ} \times 2^{\circ}$ grid to take advantage of the higher in situ data density, and (iv) prior $\mathrm{CO}_{2}$ fluxes were constructed following Weir et al. (2021).

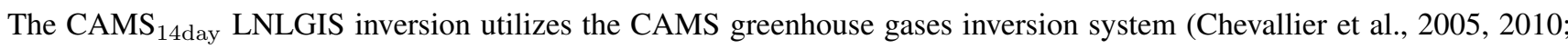
Chevallier, 2013), and assimilates OCO-2 land nadir and land glint $\mathrm{X}_{\mathrm{CO}_{2}} 10 \mathrm{~s}$ averages and in situ $\mathrm{CO}_{2}$ measurements concurrently. A variational system is employed to optimize day-time and night-time $\mathrm{NEE}$ at 8 -day temporal resolution of $1.875^{\circ} \times$ $3.75^{\circ}$ model grid. Tracer transport is performed using the Laboratoirede Météorologie Dynamique (LMDz) general circulation model version LMDz6A (Remaud et al., 2018). These data were downloaded from https://atmosphere.copernicus.eu/. Note that CAMS reports NBE - as explained earlier, we estimate NEE using GFED4.1s biomass burning emissions, as was done for the MIPv9.

The CMS-Flux 14 day LNLGIS flux inversions are performed using the set-up of Byrne et al. (2020b), which uses the Carbon Monitoring System-Flux (CMS-Flux) inversion system that has been developed under the NASA Carbon Monitoring System Flux project (https://cmsflux.jpl.nasa.gov) (Henze et al., 2007; Liu et al., 2014). These flux inversions optimize 14-day NEE and ocean fluxes by assimilating OCO-2 ACOS b10 land nadir and land glint "buddy" super-obs concurrently with in situ and 
https://doi.org/10.5194/bg-2022-40

Preprint. Discussion started: 2 March 2022

(c) Author(s) 2022. CC BY 4.0 License.

\section{(c) (i)}

flask measurements from version 6.0 of the GLOBALVIEW plus package (Masarie et al., 2014; Schuldt et al., 2020). OCO-2

"buddy" super-obs are obtained by averaging individual soundings into super-obs at $0.5^{\circ} \times 0.5^{\circ}$ spatial resolution (within the same orbit) following Liu et al. (2017). We assimilate surface-based in situ and flask measurements between 11 AM and 4 PM local time. These data were also pre-filtered to remove observations that were not well simulated by the model (based on a posterior data-model $\chi^{2}$ mismatches greater than three for a preliminary flux inversion). For these inversions, ODIAC fossil fuel emissions (Oda and Maksyutov, 2011; Oda et al., 2018) and GFED 4.1s biomass burning emissions (van der Werf et al., 2017), including small fires (Randerson et al., 2012), are prescribed but not optimized.

\subsection{Dynamic global vegetation models (DGVMs)}

We use $\mathrm{CO}_{2}$ flux estimates from an ensemble of 15 dynamic global vegetation models (DGVMs) from TRENDY v8 (Sitch et al., 2015). We utilize fluxes simulated by the CABLE-POP, CLASS-CTEM, CLM5.0, DLEM, ISAM, ISBA-CTRIP, JSBACH, JULES, LPJ, LPX-Bern, OCN, ORCHIDEE, ORCHIDEE-CNP, SDGVM and VISIT DGVMs. We exclude LPJGUESS because monthly output on $R_{h}$ was not available. We utilize monthly GPP, autotrophic respiration $\left(R_{a}\right)$ and $R_{h}$ fluxes from the "S3" experiment that employs time-varying $\mathrm{CO}_{2}$, climate and land use forcing data. We further calculate NPP from the simulated GPP and $\mathrm{R}_{\mathrm{a}}$ data $\left(\mathrm{NPP}=\mathrm{GPP}-\mathrm{R}_{\mathrm{a}}\right.$ ) at the models native resolution. The NEE, NPP, and $\mathrm{R}_{\mathrm{h}}$ fluxes produced by each ensemble member are shown in Fig. S4 for the same three year period as the data-driven estimates (2015, 2016, and 2018).

We also utilize TRENDY v8 model output to estimate an ensemble of Carbon Use Efficiency (CUE $=$ NPP/GPP) from each DGVM. CUE can become negative during the winter and spring, when GPP is approximately zero but $R_{a}$ is non-zero. However, we limit CUE values to a range between zero and one. These CUE estimates are then employed to estimate datadriven NPP estimates from the data-driven GPP data (see Sec. 2.4). Figure S5 shows the CUE estimates derived from the TRENDY v8 models.

\subsection{GPP datasets and NPP estimates}

We utilize four data-driven GPP estimates in this analysis: FluxSat, FLUXCOM, VPM, and GOSIF. These datasets differ in inputs and approach.

FluxSat Version 2 (Joiner and Yoshida, 2020) estimates GPP based on Nadir BRDF-Adjusted Reflectances (NBAR) from the MODerate-resolution Imaging Spectroradiometer (MODIS) MYD43D product (Schaaf et al., 2002). The GPP estimates are calibrated with the FLUXNET2015 GPP derived from eddy covariance flux measurements at Tier 1 sites (Pastorello et al., 2020).

FLUXCOM upscales $\mathrm{CO}_{2}$ fluxes from flux tower observations using a variety of machine learning methods and forcing datasets (Jung et al., 2020). We examine the ensemble mean of the nine remote sensing (RS) learning algorithms.

VPM is a light use efficiency model that estimates GPP globally using MODIS surface reflectances and NCEP Reanalysis-2 
https://doi.org/10.5194/bg-2022-40

Preprint. Discussion started: 2 March 2022

(c) Author(s) 2022. CC BY 4.0 License.

(c) (i)

and 8-days. VPM has been shown to agree well with FLUXNET eddy covariance site-level data (Zhang et al., 2017) and with TROPOMI SIF at the global scale (Doughty et al., 2021).

The GOSIF GPP product estimates GPP based on OCO-2 SIF, MODIS EVI, and reanalysis data from MERRA-2 (Li and Xiao, 2019). To generate GPP estimates, first, 8 day globally gridded $0.05^{\circ} \times 0.05^{\circ}$ SIF is estimated from the input data using machine-learning algorithms. GOSIF GPP is then estimated from the GOSIF SIF estimates using eight SIF-GPP relationships with different forms (universal and biome-specific, with and without intercept). In this analysis we utilize the mean GPP estimate across the eight SIF-GPP estimates.

These four data-driven GPP estimates are shown in Fig. S6. For this analysis, we estimate NPP from these data using the CUE from the TRENDY models. We perform this calculation differently for the monthly analysis and biweekly analysis. For the monthly analysis, we calculate 60 NPP seasonal cycles for each possible combination of the four GPP and 15 CUE seasonal cycles. We then calculate the median as our best estimate and interquartile range as a metric of uncertainty. For the biweekly analysis, we calculate the best estimate using the median GPP and CUE seasonal cycles, and calculate the uncertainty using the full range of GPP estimates and interquartile range of CUE estimates. This is done differently to match the NEE analysis, which leverages the larger ensemble from the MIPv9 to examine the median and interquartile spread for the monthly analysis, but employs the full range for the smaller biweekly ensemble of three models.

\subsection{Data-driven $R_{h}$ estimates}

We calculate the seasonal cycle of $\mathrm{R}_{\mathrm{h}}$ by combining the data-driven estimates of NPP and NEE,

$\mathrm{R}_{\mathrm{h}}=\mathrm{NEE}+\mathrm{NPP}$.

We perform this calculation differently for the monthly analysis and biweekly analysis. For the monthly OCO-2 MIPv9 IS- and LNLG-based estimates, we calculate $540 \mathrm{R}_{\mathrm{h}}$ seasonal cycles by combining the nine data-driven IS or LNLG NEE estimates with the 60 NPP estimates. We then take the median and interquartile spread as the best estimate and uncertainty. For the biweekly analysis, we calculate the best estimate of $R_{h}$ from the best (median) estimates of NPP and NEE. We then take the uncertainty to be the full range of $R_{h}$ estimates calculated from the three biweekly NEE estimates and the NPP range.

\subsection{Soil carbon decomposition model}

We use the soil carbon decomposition model developed in Yi et al. $(2015,2020)$ to simulate the contribution of soil at different depths to total $R_{h}$ and NEE fluxes. The soil decomposition model uses multiple litter and SOC pools to characterize the progressive decomposition of fresh litter to more recalcitrant materials, which include three litterfall pools, three SOC pools with relatively fast turnover rates, and a deep SOC pool with slow turnover rates. The litterfall carbon inputs were first allocated to the three litterfall pools depending on the substrate quality of litterfall component and then transferred to the SOC pools through progressive decomposition. We then model the profile of the carbon pools through accounting for the vertical carbon transport (Yi et al., 2020). A constant diffusivity rate was assigned to permafrost $\left(5.0 \mathrm{~cm}^{2} \mathrm{yr}^{-1}\right)$ and non-permafrost $\left(2.0 \mathrm{~cm}^{2} \mathrm{yr}^{-1}\right)$ regions within the top $1 \mathrm{~m}$ soil, and then linearly decreased to 0 at the $3 \mathrm{~m}$ below surface (Koven et al., 2013). The boundary 
https://doi.org/10.5194/bg-2022-40

Preprint. Discussion started: 2 March 2022

(c) Author(s) 2022. CC BY 4.0 License.

(c) (i)

conditions at the soil surface were set as the carbon input rate to the three surface litterfall pools. A zero-flux was assigned at the bottom of the soil carbon pool, which was set as $3 \mathrm{~m}$. This accounts for the upper permafrost layer, while carbon in deeper layers (e.g., 3-10 m) is largely insulated from climate variability and ignored in this study. The decomposition rate $\left(\right.$ day $\left.^{-1}\right)$ for each carbon pool was derived as the product of a theoretical maximum rate constant and dimensionless multipliers for soil temperature and liquid water content constraints (Yi et al., 2015) to decomposition indicated by the MERRA2 soil temperature data. For simplicity, the soil saturation was assumed as 1.0 when soil temperature is above $0{ }^{\circ} \mathrm{C}$, while the maximum liquid soil water fraction was used for below freezing (Schaefer and Jafarov, 2016).

\subsection{FLUXNET data and processing}

We examine 15 high latitude FLUXNET2015 sites to confirm the seasonality of carbon fluxes inferred from the atmospheric $\mathrm{CO}_{2}$ and remote sensing datasets. These sites are listed in table S1. For this, we utilize monthly data with the quality flag greater than 0.75 . We calculate NPP and $R_{h}$ for each site from the NEE and GPP datasets by applying the CUE from the TRENDY DGVMs at the gridcell containing the FLUXNET site.

\section{Results}

\subsection{Differences between data-driven and DGVM carbon fluxes}

We first examine the mean seasonal cycle of monthly NEE from the MIPv9 inversions and TRENDY v8 DGVMs over the three north Eurasian regions (mean over 2015, 2016, and 2018; 2017 is excluded due to an OCO-2 data gap). The objective of this initial analysis is to identify the seasonal features of NEE over northern Eurasia, and identify how the data-driven and simulated estimates differ. The spread among the TRENDY v8 models is large and encompasses the data-driven estimates (Fig. S4). Thus, to identify data-model differences, we focus on differences in the ensemble median estimates and adopt the interquartile spread across MIPv9 and TRENDY to quantify uncertainty in this estimate.

Figure 2(a-c) shows the NEE fluxes for the MIPv9 and TRENDY DGVMs for three regions over Eurasia. The two OCO-2 MIPv9 ensembles (IS and LNLG) generally show close agreement and coherent differences from the TRENDY models (and prior NEE estimates, Fig. S2). The largest differences between the IS and LNLG ensembles occur over the Cold region, where the IS ensemble suggests increased uptake during July and somewhat increased release during October. Still, the coherent differences between the data-driven fluxes (both IS and LNLG) relative to the TRENDY ensemble gives us increased confidence that these inversions are precisely capturing the seasonality of NEE. The comparatively good agreement between the IS and LNLG inversions (relative to TRENDY) also suggests that artifacts related to observational coverage (Byrne et al., 2017; Basu et al., 2018) and data/model biases (Schuh et al., 2019) do not strongly impact the results. Although, we note that both datasets have spatial and seasonal gaps over northern Eurasia (e.g., Fig. S8-S9) as discussed in Sec. 4.2. The accuracy of the MIPv9 fluxes is supported through an evaluation of the posterior $\mathrm{CO}_{2}$ fields against independent atmospheric $\mathrm{CO}_{2}$ measurements by 
https://doi.org/10.5194/bg-2022-40

Preprint. Discussion started: 2 March 2022

(c) Author(s) 2022. CC BY 4.0 License.
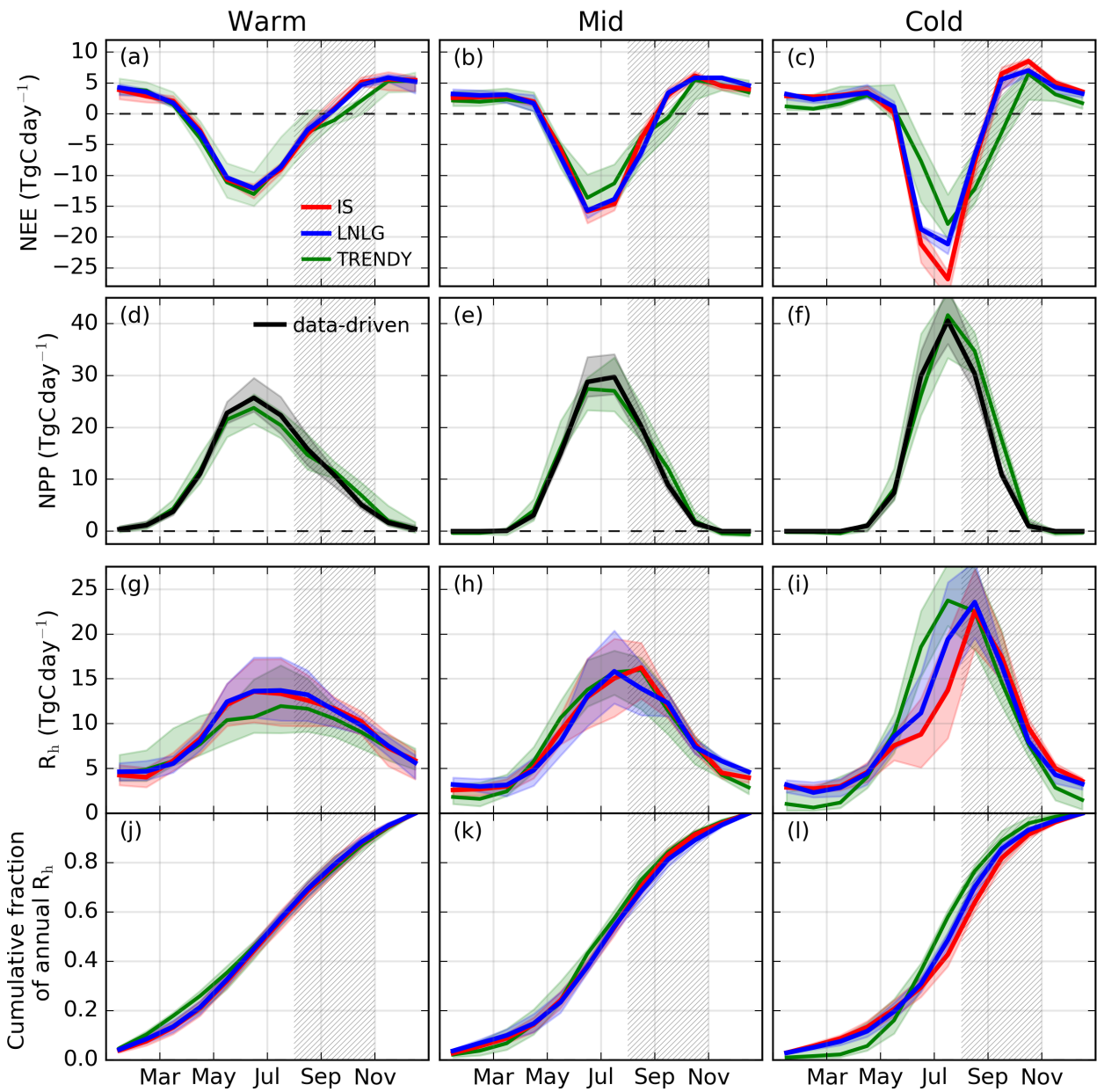

Figure 2. Monthly carbon cycle fluxes (average of 2015, 2016 and 2018; 2017 is excluded due to an OCO-2 data gap). (a-c) Median (solid line) and interquartile range (shaded area) of NEE for the ensemble of IS (red) and LNLG (blue) OCO-2 MIPv9 and for the TRENDY ensemble (green). (d-f) NPP for the TRENDY ensemble (green) and estimated from data-driven GPP (black). (g-i) $\mathrm{R}_{\mathrm{h}}$ simulated by the TRENDY ensemble (green) and calculated from combining the data-driven GPP with the IS (red) and LNLG (blue) OCO-2 MIPv9 NEE constraints. (j-1) Cumulative fraction of $R_{h}$ over the growing season. Figure $S 7$ shows these fluxes per unit area.

Peiro et al. (2021), and a supplementary comparisons of the CMS-Flux ${ }_{14 \text { day }}$ inversions with aircraft data over Alaska (Text. S1, Fig. S10-S11).

Comparing the MIPv9 and TRENDY NEE estimates, good agreement is found for the Warm and Mid regions, while larger differences are found for the Cold region. In the Warm and Mid regions, systematic differences exceed the interquartile range during Sep-Oct, when the TRENDY models suggest a weaker efflux of $\mathrm{CO}_{2}$ to the atmosphere (2.19-2.47 $\mathrm{TgCday}^{-1}$ ). The TRENDY models also tend to show weaker uptake by land during June-July in the Mid region (2.32-2.77 $\mathrm{TgCday}^{-1}$ ). For 
https://doi.org/10.5194/bg-2022-40

Preprint. Discussion started: 2 March 2022

(c) Author(s) 2022. CC BY 4.0 License.

\section{(c) $\underset{\mathrm{BY}}{\mathrm{BV}}$}

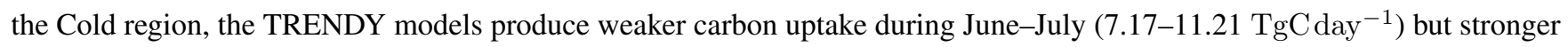
uptake (or reduced efflux) during Aug-Oct (4.86-5.33 $\mathrm{TgCday}^{-1}$ ). This large amplitude of the NEE seasonal cycle contributes to the large seasonality in $\mathrm{X}_{\mathrm{CO}_{2}}$ observed over eastern Eurasia (Jacobs et al., 2021).

To further investigate the causes of differences in NEE between the TRENDY and MIPv9 ensembles, we separately examine NPP and $R_{h}$. The data-driven NPP and TRENDY NPP are shown in Fig. 2(d-f). The seasonality in NPP between the data-driven and TRENDY estimates show good agreement for all regions. In the Mid and Warm regions, the TRENDY model median tends to be lower than the data-driven estimates during Jun-Jul (1.94-2.01 $\left.\mathrm{TgC}_{\text {day }}{ }^{-1}\right)$. However, the largest differences are for the Cold region, where the TRENDY ensemble median shows increased NPP during Aug-Sep (5.64 $\mathrm{TgCday}^{-1}$ ). This largely accounts for the lower NEE during Aug-Sep (86-95\%). Thus, despite previously reported deficiencies in model representation of photosynthesis over high latitudes (Rogers et al., 2017, 2019), we find that TRENDY NPP largely capture the data-driven seasonality and do not drive NEE differences against the data-driven seasonal cycle.

Finally, we compare TRENDY $R_{h}$ to data-driven $R_{h}$ (Fig. 2(g-i)). In the Warm region, the TRENDY model median $R_{h}$ is lower than the data-driven estimates during May-Sep (2.28-2.47 $\left.\mathrm{TgC} \mathrm{day}^{-1}\right)$, but the seasonality is similar. In the Mid region, the data-driven and TRENDY $\mathrm{R}_{\mathrm{h}}$ seasonal cycles show good agreement throughout the growing season. The largest differences between data-driven and TRENDY $R_{h}$ seasonal cycles are found for the Cold region. The TRENDY model median shows increased $\mathrm{R}_{\mathrm{h}}$ during May-Jul (4.05-7.07 $\mathrm{TgC}_{\text {day }}{ }^{-1}$ ) but show reduced $\mathrm{R}_{\mathrm{h}}$ during the rest of the year $\left(1.37-1.69 \mathrm{TgC} \mathrm{day}^{-1}\right)$. As a result, the seasonality of data-driven $R_{h}$ is shifted later in the year relative to TRENDY ensemble. This can be seen in the cumulative fraction of annual $R_{h}$, which quantifies the fraction of total $R_{h}$ released as the season progresses (Fig. 2(j-1)). The percentage of total annual Rh released during May-Jul is 48\% for the TRENDY ensemble median but 36\% (30\%) for the LNLG (IS) data-driven $\mathrm{R}_{\mathrm{h}}$ ensemble median.

We independently confirm a shift in the seasonality of data-driven $R_{h}$ relative to TRENDY for 15 high latitude FLUXNET sites (Fig. S12). Due to the sparsity of FLUXNET sites over northeastern Eurasia, we include sites outside of the "Cold" domain but that have early zero-crossing dates (estimated by a mean October air temperature less than $2{ }^{\circ} \mathrm{C}$ ). The observed median $R_{h}$ peaks across these sites during September, in agreement with the data-driven $R_{h}$ seasonality. In contrast, the TRENDY median $R_{h}$ peak occurs during July (consistent with the regional scale analysis). This phase shift is also evident in the cumulative fraction of annual $R_{h}$, which shows that the percentage of total annual $\mathrm{Rh}$ released during May-Jul is $46 \%$ for the TRENDY ensemble median but $35 \%$ for the FLUXNET-based ensemble median.

Overall, these results indicate good agreement between the TRENDY ensemble and data-driven estimates for the Warm and Mid regions, but show marked differences over the Cold region. In particular, we find that the data-driven estimates suggest a seasonal redistribution of $\mathrm{R}_{\mathrm{h}}$ with a reduction during May-Jul but an increase for the remainder of the year. Further, these results show that differences in $R_{h}$ largely account for the differences between the data-driven and TRENDY NEE fluxes over the Cold region, except in Aug-Sep when NPP differences are large. In the remaining sections, we will characterize the datadriven seasonal cycle of NEE, NPP, and $\mathrm{R}_{\mathrm{h}}$ at a higher (biweekly) temporal resolution and investigate mechanistic explanations for the data-model differences found over the Cold region. 
https://doi.org/10.5194/bg-2022-40

Preprint. Discussion started: 2 March 2022

(c) Author(s) 2022. CC BY 4.0 License.

\section{(c) (i)}

\subsection{Data-driven biweekly $\mathrm{CO}_{2}$ fluxes}

We now investigate the data-driven seasonal cycle of NEE, NPP, and $\mathrm{R}_{\mathrm{h}}$ with biweekly (14 day) temporal resolution. This higher resolution better resolves temporal changes in $\mathrm{CO}_{2}$ fluxes throughout the growing season, particularly during the shoulder seasons, when week-to-week changes in $\mathrm{CO}_{2}$ fluxes are large (Parazoo et al., 2018a). For this analysis, we utilize a set of three flux inversions that assimilate both in situ and OCO-2 land nadir and glint data (ACOS v10) to estimate sub-monthly $\mathrm{CO}_{2}$

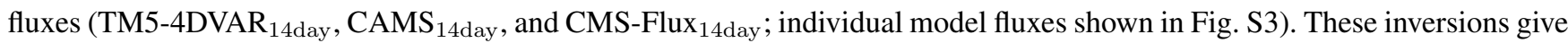
similar NEE seasonality to the MIPv9 monthly fluxes (e.g., Fig S10) and have seasonality similar to the OCO-2 MIPv9 LNLG inversions for the Cold region. For NPP, we utilize the same datasets as Sec. 3.1 but at 14-day temporal resolution. We examine the ensemble medians for a best estimate and take the full range of model estimates as an illustration of the uncertainty.

Figure 3 shows the four-year-mean (2015, 2016, 2018, and 2019; 2017 is excluded due to an OCO-2 data gap in summer) seasonal cycle of NEE, NPP, and $R_{h}$ for the three regions of Eurasia. NEE largely tracks the inverted seasonality of NPP, although peak NPP is slightly delayed relative to peak drawdown in NEE (by 0-2 weeks). Both NEE and NPP generally follow the seasonal cycle of insolation, but are somewhat delayed in the Mid and Cold regions, likely due to temperature limitation (Liu et al., 2020). Peak $R_{h}$ is found to be delayed relative to peak NPP by $0-8$ weeks. For the Warm and Mid regions, $R_{h}$ follows the seasonal cycle of surface temperature, with $48 \%$ and $51 \%$ of the annual total $\mathrm{R}_{\mathrm{h}}$ occurring after the peak in surface temperature, respectively. In contrast, the Cold region shows a substantial delay relative to surface temperature, with $63 \%$ of the total $R_{h}$ occurring after the peak in surface temperature. The median $R_{h}$ seasonal cycle is also found to have a double peak in this Cold region: a smaller peak of $9.8 \mathrm{TgC} \mathrm{day}^{-1}$ occurs during late May followed by a larger peak of $21.5 \mathrm{TgC} \mathrm{day}^{-1}$ at the beginning of September. This May peak roughly aligns with the spring thaw and positive zero-crossing at the beginning of May. A potential mechanistic explanation for a spring pulse of $\mathrm{R}_{\mathrm{h}}$ could be due to thawing soils that release $\mathrm{CO}_{2}$ that has been trapped within subsurface soil layers over the winter (see Sec. 4). However, the signal from this first peak is small relative to the uncertainties.

\subsection{Mechanistic drivers of late-season $\mathbf{R}_{h}$}

Data-driven $R_{h}$ for the Cold region indicates a delayed peak relative to surface temperature and the TRENDY model median. Here we examine possible mechanistic explanation for this late season peak in $\mathrm{R}_{\mathrm{h}}$ using models. We investigate two factors that could potentially contribute to the delay in $\mathrm{R}_{\mathrm{h}}$ : (1) Seasonal variations in the labile carbon pool. Leaf and fine root litter carbon pools tend to increase over the growing season as carbon is sequestered through photosynthesis (Randerson et al., 1996). Thus, increased substrate availability in the autumn relative to the spring will act to shift the seasonal cycle of $\mathrm{R}_{h}$ later in the year. (2) $R_{h}$ from subsurface soil layers that have a delayed seasonal cycle driven by a lag in soil temperature. Heating and cooling at the surface slowly diffuses through the soil column resulting in a lagged seasonal cycle of temperature with depth (Parazoo et al., 2018b). Figure 4(a-c) shows the seasonal cycle in soil temperature from the MERRA-2 Land dataset. The phase shift in soil temperature seasonality with depth can be up to several months, and is largest for the colder regions. Note that we verify 
https://doi.org/10.5194/bg-2022-40

Preprint. Discussion started: 2 March 2022

(c) Author(s) 2022. CC BY 4.0 License.

(c) (i)
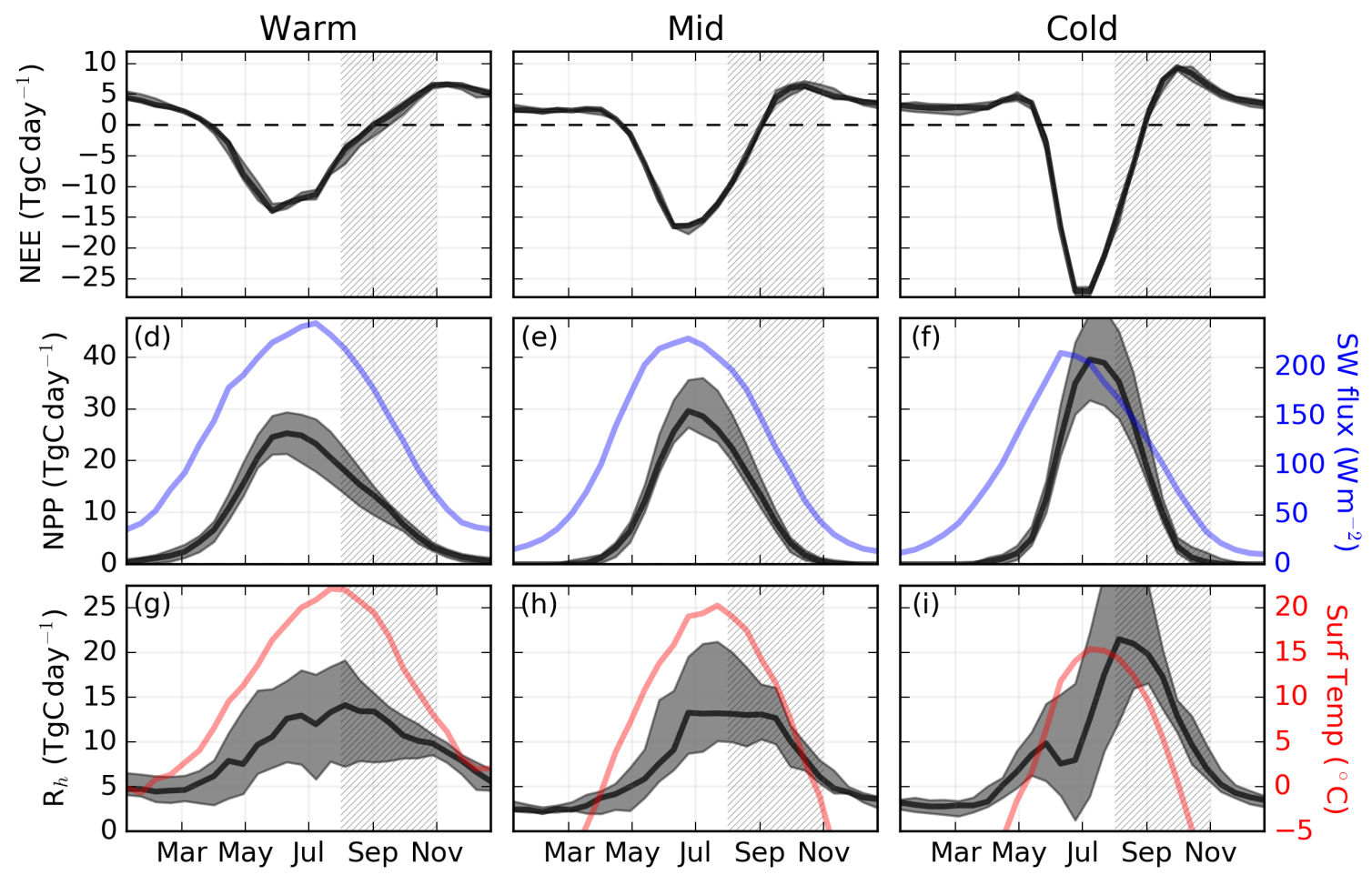

Figure 3. Data-driven four-year-mean (2015, 2016, 2018, and 2019) 14-day NEE, NPP, and Rh. (a-c) Median and ensemble spread of NEE for the CMS-Flux ${ }_{14 d a y}$, TM4-4DVar ${ }_{14 \text { day }}$, and CAMS ${ }_{14 \text { day }}$ flux inversions. (d-f) Median and ensemble spread for the data-driven NPP. MERRA-2 Land net downward shortwave flux over land is shown in blue. (g-i) Ensemble estimate of $R_{h}=$ NEE + NPP estimated from the three NEE and GPP estimates. MERRA-2 Land surface temperature is shown in red.

the fidelity of the MERRA-2 Land soil temperature against borehole measurements and against simulated soil temperature from ERA-5 reanalysis and the CMIP6 models (see Text. S2, Fig. S13-S14).

To test the impact of these factors, we consider a single layer model that represents $R_{h}$ using a exponential relationship with temperature:

$\mathrm{R}_{\mathrm{h}}=\alpha e^{\beta \mathrm{T}}$,

where $\alpha$ represents the labile carbon pool size, $\beta$ is a constant, and $\mathrm{T}$ is the temperature of the carbon pool. To investigate the impact of seasonal and vertical variations in labile carbon, we consider three cases:

1. The carbon pool is constant in time and the surface temperature $\left(T_{\text {surf }}\right)$ drives $R_{h}$,

2. The carbon pool is constant in time and the average top meter soil temperature $\left(T_{1 \mathrm{~m}}\right)$ drives $R_{h}$, 

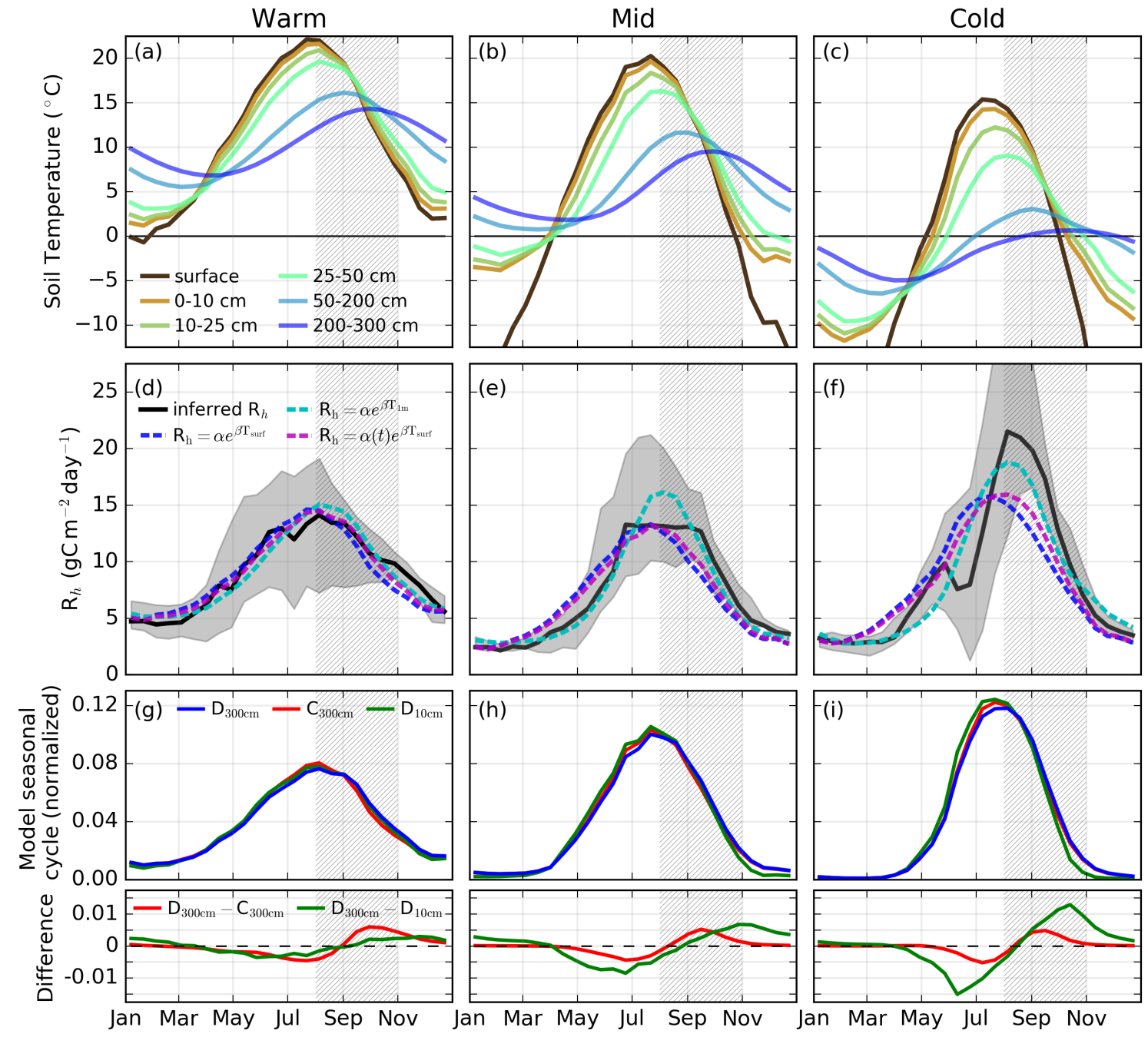

Figure 4. Impact of temporal and vertical variations in carbon pools on $\mathrm{R}_{\mathrm{h}}$. (a-c) MERRA-2 Land soil temperature over five intervals for the (a) Warm, (b) Mid, and (c) Cold regions. (d-e) Median and range in inferred 14-day $\mathrm{R}_{h}$ with fits for single-layer $\mathrm{R}_{\mathrm{h}}$ models that employ (navy dash) $\mathrm{T}_{\text {surf }}$ dependence and no seasonal variations in the carbon pool, (cyan dash) $\mathrm{T}_{1 \mathrm{~m}}$ dependence and no seasonal variations in the carbon pool and (magenta dash) $\mathrm{T}_{\text {surf }}$ dependence and seasonal variations in the carbon pool. (g-i, top) Normalized seasonal cycle of $\mathrm{R}_{\mathrm{h}}$ simulated for $\mathrm{D}_{300 \mathrm{~cm}}$ (dynamic carbon pool over 0-300 cm depth), $\mathrm{C}_{300 \mathrm{~cm}}$ (constant carbon pool over 0-300 cm depth), $\mathrm{D}_{10 \mathrm{~cm}}(\mathrm{dynamic}$ carbon pool over 0-10 cm depth) and (g-i, bottom) the difference in simulated $\mathrm{R}_{\mathrm{h}}$.

3. The carbon pool is dynamic in time ( $\alpha=f(t)$, described in the Appendix) and the $\mathrm{T}_{\text {surf }}$ drives $\mathrm{R}_{\mathrm{h}}$. We assume seasonal variations in the carbon pool are within $\pm 15 \%$ of the mean $(\gamma=0.15$, Fig. S15 shows the seasonal variation in the labile carbon pool). 
https://doi.org/10.5194/bg-2022-40

Preprint. Discussion started: 2 March 2022

(c) Author(s) 2022. CC BY 4.0 License.

\section{(c) (i)}

Figure 4(d-f) shows linear regressions for each one-layer model against the median biweekly estimate of $R_{h}$. In each case, the parameters $\alpha$ and $\beta$ are optimized (note linear regressions are performed on $\ln \left(R_{h}\right)=\ln (\alpha)+\beta T$ ). For the Warm region, all models are able to fit the data well $\left(\mathrm{R}^{2}=0.89-0.94\right)$. Similarly, all models are able to largely capture the seasonal cycle in the Mid region $\left(\mathrm{R}^{2}=0.84-0.92\right)$, although the model driven by $\mathrm{T}_{1 \mathrm{~m}}$ appears to better capture the shoulder seasons. The models diverge the most for the Cold region. The model driven by $\mathrm{T}_{\text {surf }}$ with a constant carbon pool gives the poorest performance $\left(\mathrm{R}^{2}=0.65\right)$, as the driving temperature data peaks too early to capture the seasonality of $\mathrm{R}_{\mathrm{h}}$. The model with a dynamic carbon pool performs somewhat better as the peak in model $R_{h}$ is delayed relative to surface temperature. Still, the model driven by $T_{1 \mathrm{~m}}$ performs the best $\left(\mathrm{R}^{2}=0.88\right)$, and best captures the delayed $\mathrm{R}_{\mathrm{h}}$ seasonality relative to surface temperature. This analysis demonstrates that the seasonality of $\mathrm{R}_{\mathrm{h}}$ in the Warm and Mid regions are reasonably explained by seasonal variations in $\mathrm{T}_{\text {surf }}$, but that inclusion of seasonal variations in the labile carbon pool and the impact of soil temperature with depth still improve the seasonal fit. However, for the Cold region, the seasonality of $R_{h}$ is not well captured by $T_{\text {surf }}$ and additional factors, particularly the impact soil temperature with depth, are required to explain the delayed seasonality of $R_{h}$ over the Cold region.

We further investigate these mechanisms using a soil carbon decomposition model that can resolve seasonal and vertical variations in carbon pools (Sec. 2.6). We examine the seasonality of the $\mathrm{R}_{\mathrm{h}}$ simulated down to a depth of $300 \mathrm{~cm}$ using a constant carbon pool $\left(\mathrm{C}_{300 \mathrm{~cm}}\right)$, simulated within the top $10 \mathrm{~cm}$ of soil using a dynamic carbon pool $\left(\mathrm{D}_{10 \mathrm{~cm}}\right)$, and simulated to a depth of $300 \mathrm{~cm}$ using a dynamic carbon pool $\left(\mathrm{D}_{300 \mathrm{~cm}}\right)$. We compare these seasonal cycles after normalizing by the annual total $R_{h}$. Figure $4(g-i)$ shows that incorporating seasonal and vertical variations in the carbon pool results in a phase shift in $\mathrm{R}_{\mathrm{h}}$ to later in the year, consistent with the one-layer model results. The simulated impact of these factors is found to be quite small, possibly due to underestimation of the impact of seasonal and vertical variations in the carbon pools on $\mathrm{R}_{\mathrm{h}}$ in the model. Still, these model simulations can inform the $\mathrm{R}_{\mathrm{h}}$ tendencies of these carbon pool variations. Comparing the regions, the impact of seasonal variations in the labile carbon pool are quite similar, with reduced $R_{h}$ in the summer and increased $R_{h}$ during the autumn relative to a constant carbon pool. In contrast, the impact of vertically resolved $R_{h}$ shows differences between the regions, with a small impact for the Warm region but a comparatively large impact for the Cold region. The larger impact over the Cold region is likely due to larger carbon pools at depth (Fig. S16), with a possible contribution from regional differences in the thermal gradient with depth (Fig. 4). Similarly, we find that the fractional contribution of subsurface soils to total $R_{h}$ has larger seasonal variation over the Cold region (Fig. S17). Thus, these results support a substantial contribution of subsurface soil $\mathrm{R}_{\mathrm{h}}$, and suggests that an underestimation of this quantity by the DGVMs could explain the data-model differences.

\section{Discussion}

\subsection{Implications}

Over the cold northeastern region of Eurasia, our data-driven $\mathrm{R}_{\mathrm{h}}$ seasonal cycle allocates $64-70 \%$ of annual $\mathrm{CO}_{2}$ emissions to outside of the summer (August - April) compared to only $52 \%$ of annual $\mathrm{R}_{\mathrm{h}}$ emissions allocated by the TRENDY DVGMs to this period. The reason that the TRENDY models do not capture this seasonality is unclear. A plausible explanation is that the TRENDY models do not capture the contribution of subsurface layers to $R_{h}$, especially during the zero curtain period. 
https://doi.org/10.5194/bg-2022-40

Preprint. Discussion started: 2 March 2022

(c) Author(s) 2022. CC BY 4.0 License.

\section{(c) (i)}

This is clearly the case for the subset of TRENDY models that drive $R_{h}$ with air temperature. However, it is unclear if this is an important factor for models with more sophisticated soil modules. Surprisingly, a preliminary analysis did not find a relationship between model complexity and agreement with the data-driven estimate. The drivers of differences from the datadriven estimate may differ between models, and be impacted by the interplay of litterfall phenology, $R_{h}$ formulation (Peylin et al., 2005), and number of soil layers, among other factors. Some potential areas of focus for improving models may be gleaned from recent studies. Seiler et al. (2021) suggest that the TRENDY models may systematically underestimate soil organic carbon at high latitudes, which could contribute to an underestimate of subsurface $\mathrm{R}_{\mathrm{h}}$ across the models. Endsley et al. (2021) found a similarly phased bias in simulated $R_{h}$ by the Terrestrial Carbon Flux (TCF) model against flux tower $R_{h}$ to that reported here. They show that this bias could be largely mitigated by adding seasonally varying litterfall phenology, an $\mathrm{O}_{2}$ diffusion limitation on $\mathrm{R}_{\mathrm{h}}$ and a vertically resolved soil decomposition model, suggesting these may be foci for model improvements.

Differences between the data-driven and TRENDY $R_{h}$ seasonal cycles suggest that DGVMs may be deficient in simulating the response of permafrost rich ecosystems to climate change, particularly in terms of subsurface $R_{h}$. Improving DGVM skill in these ecosystems is critical given the rapid northern high latitude warming and lengthening of the zero curtain period (Euskirchen et al., 2017; Parazoo et al., 2018b; Chen et al., 2021). The rapid changes in northern Eurasia are illustrated in Fig. 5, which shows the number of months per year that soil temperatures are greater than $0{ }^{\circ} \mathrm{C}$ as simulated by a set of CMIP6 models. Soils in the permafrost-rich Cold region are undergoing the most dramatic lengthening of the unfrozen period, particularly at depth (50-200 cm). Under scenario ssp585 (highest emission scenario), these soils are predicted to go from $\sim 5$ months per year with a monthly mean soil temperature above $0{ }^{\circ} \mathrm{C}$ during the 20 th century to $\sim 11$ months per year by 2100. The impact is largest for the Cold region at depth because of the reduced seasonality relative to the surface, such that a warming of $\sim 7^{\circ} \mathrm{C}$ shifts nearly the entire seasonal cycle above $0{ }^{\circ} \mathrm{C}$ at a depth of 50-200 cm (Fig. S18). Such warming would drive the widespread formation of talik, a subsurface layer of perennial thawed soil (Parazoo et al., 2018b), and further enhance $\mathrm{R}_{\mathrm{h}}$ at depth.

$\mathrm{R}_{\mathrm{h}}$ from sub-surface layers may already be increasing substantially in permafrost regions. Examining the 41 year record of $\mathrm{CO}_{2}$ at Barrow tower, Commane et al. (2017) find that early cold NEE efflux (Oct-Dec) has increased 73.4\% $\pm 10.8 \%$ over the 1975-2015 period. The standard CAMS IS inversion product similarly suggests an increase in the Sep-Oct NEE efflux of $\sim 80 \%$ over Siberia for the 2013-2017 period relative to the 1980-1984 period (see Fig. S20 of Lin et al. (2020)). In agreement, Hu et al. (2021) identified a strong increase $(\sim 10 \%)$ in Aug-Oct $\mathrm{R}_{\mathrm{h}}$ over the North America Arctic-boreal region between 1979-1988 and 2010-2019 based on measurements of atmospheric $\mathrm{CO}_{2}$ and carbonyl sulphide.

\subsection{Limitations}

Atmospheric $\mathrm{CO}_{2}$ measurements are relatively sparse over Northern Eurasia (Byrne et al., 2017). In situ and flask $\mathrm{CO}_{2}$ measurements are spatially sparse over Mid and Cold regions (Fig. S9), with only a handful of sites assimilated over Russia as part of Japan-Russia Siberian Tall Tower Inland Observation Network (JR-STATION) of nine tower sites (Sasakawa et al., 2010, 2013). The OCO-2 coverage is seasonally variable (Fig. S8). Due to the fact that $\mathrm{X}_{\mathrm{CO}_{2}}$ retrievals are performed on re- 
https://doi.org/10.5194/bg-2022-40

Preprint. Discussion started: 2 March 2022

(c) Author(s) 2022. CC BY 4.0 License.
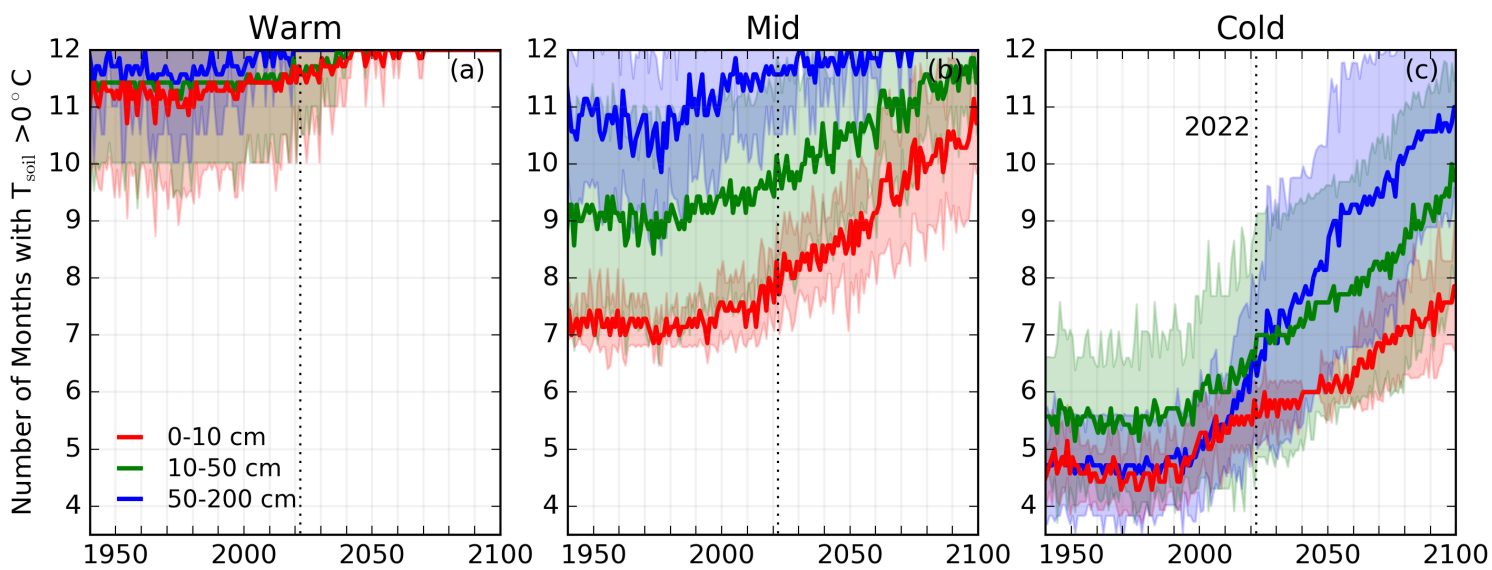

Figure 5. Number of months per year with monthly mean soil temperatures above $0{ }^{\circ} \mathrm{C}$ at depths of $0-10 \mathrm{~cm}$ (red), $10-50 \mathrm{~cm}$ (green), and 50-200 cm (blue) simulated by seven CMIP6 models under ssp585 for the (a) Warm, (b) Mid, and (c) Cold regions. The solid lines show the model mean and shading shows \pm 1 standard deviation.

flected sunlight, the coverage across Eurasia is quite good during the growing season (May-Sep). However, low signal and the inability to perform retrievals over snow limits the data coverage during the shoulder seasons and winter, resulting in few $\mathrm{X}_{\mathrm{CO}_{2}}$ retrievals across the Mid and Cold regions during Nov-Feb. Ongoing research to both improve $\mathrm{X}_{\mathrm{CO}_{2}}$ quality control filtering at high latitudes (Jacobs et al., 2020; Mendonca et al., 2021) and in retrievals $\mathrm{X}_{\mathrm{CO}_{2}}$ over snow and ice surfaces (Mikkonen et al., 2021) may reduce these data gaps in the future. Despite this sparsity of measurements, we find that the LNLG and IS flux inversions show consistent differences from the TRENDY and prior fluxes. Furthermore, these data show good agreement with withheld in site data (Peiro et al., 2021) and independent aircraft measurements over Alaska (Fig S11). Thus, we believe the results presented here to be robust despite data gaps. Still, this sparsity of data leads to some limitations. There are few sources of independent $\mathrm{CO}_{2}$ measurements over the $\mathrm{Mid}$ and Cold regions to evaluate the inversion posterior $\mathrm{CO}_{2}$ fields against. Independent measurements (possibly aircraft campaigns) would provide a valuable additional data set for validation. Similarly, increasing the number of year-round eddy-covariance sites across the Mid and Cold regions would provide a valuable independent dataset to compare against flux inversion estimated NEE. For example, Byrne et al. (2020a) were able to confirm top-down estimate of east-west differences in NEE interannual variability across North America against the dense network of eddy-covariance sites.

We also note that there are challenges in estimating data-driven GPP during the shoulder season due to reduced reflected radiance and snow cover, which impacts the spectral features of the vegetation canopy. Poor quality data, such as snowy and noisy samples, contributes to uncertainty in the timing of shoulder seasons (Wang et al., 2017; Zhang, 2015). In this analysis, we attempted to mitigate this issue though the use of an ensemble of data-driven GPP estimates, but we acknowledge that remaining biases may be present. 
https://doi.org/10.5194/bg-2022-40

Preprint. Discussion started: 2 March 2022

(c) Author(s) 2022. CC BY 4.0 License.

\section{(c) (i)}

Furthermore, the partitioning of NEE into NPP and $R_{h}$ could be biased if CUE estimates were seasonally biased. We employed TRENDY model CUE to translate data-driven constraints on NEE and GPP into estimates of NPP and $R_{h}$. Thus, systematic errors across the TRENDY ensemble in CUE could impact conclusions about the relative contributions of errors in NPP and $R_{h}$. A potential source of bias in CUE could be due to an underestimate of the impact of inhibition of leaf respiration by light (Wehr et al., 2016; Byrne et al., 2018; Keenan et al., 2019; Oikawa et al., 2017). This would result in greater CUE and NPP during June-July relative to the rest of the year, shifting the inferred $R_{h}$ seasonal cycle earlier, with $R_{h}$ increased during June-July but decreased elsewhere (Byrne et al., 2018). However, the magnitude of this impact on the ecosystem scale is uncertain, making accounting for this phenomena challenging. Recently, Endsley et al. (2021) found that the inhibition of leaf respiration by light to have a relatively modest impact on the seasonality of NPP and $R_{h}$, suggesting that the results presented here are robust.

There are also remaining challenges in relating the inferred fluxes to underlying processes. Space-based flux constraints do not discriminate between biological and physical processes driving carbon cycle fluxes. It is currently unclear whether the substantial cold season $\mathrm{CO}_{2}$ effluxes across permafrost regions are driven primarily by biological activity or physical processes (Natali et al., 2019; Arndt et al., 2020; Raz-Yaseef et al., 2017). Yet, isolating the primary driver of these fluxes is critical for inferring the sensitivity of $R_{h}$ to climate change. If the cold season $R_{h}$ comes from the metabolism of old permafrost carbon, then ${ }^{14} \mathrm{CO}_{2}$ measurements could help differentiate biological from physical $\mathrm{CO}_{2}$ production.

\section{Conclusions}

Space-based and in situ atmospheric $\mathrm{CO}_{2}$ measurements revealed strong summer uptake and early cold season release of $\mathrm{CO}_{2}$ over the cold northeastern Eurasia region, implying a late summer peak in $\mathrm{R}_{\mathrm{h}}$ with substantial early cold season respiration. Based on model simulations of $R_{h}$, we suggested that this seasonality is driven by a large contribution of subsurface soils to the total $\mathrm{R}_{\mathrm{h}}$. These results are consistent with site-level observations identifying substantial $\mathrm{CO}_{2}$ release in permafrost regions outside the growing season (Natali et al., 2019), and in particular, reported spikes in early cold season respiration associated with the zero curtain period in Arctic ecosystems (Commane et al., 2017; Jeong et al., 2018).

The data-driven seasonality of $\mathrm{R}_{\mathrm{h}}$ over the Cold region was generally not captured by the TRENDY DGVMs, which showed greater $R_{h}$ during May-Jul and lower $R_{h}$ during the rest of the year. The underlying cause of this discrepancy is unclear, but may be linked to an underestimate of the contribution of sub-surface soils to total $\mathrm{R}_{\mathrm{h}}$. Given the rapid warming of permafrost soils (Euskirchen et al., 2017; Chen et al., 2021), talik formation (Parazoo et al., 2018b), and increasing early cold season $\mathrm{CO}_{2}$ effluxes (Commane et al., 2017; Lin et al., 2020; Hu et al., 2021), improving DGVM simulations in permafrost regions should be a focus of future studies.

This analysis demonstrates the utility of space-based observations for studying carbon cycle dynamics at high latitudes, where in situ measurements are sparse. Although currently limited by a short observing record (2014 - present), the estimates of NEE inferred from the OCO-2 $\mathrm{X}_{\mathrm{CO}_{2}}$ retrievals suggest that these data will provide a powerful tool for detecting change in seasonal cycle of NEE across northern Eurasia. 
https://doi.org/10.5194/bg-2022-40

Preprint. Discussion started: 2 March 2022

(c) Author(s) 2022. CC BY 4.0 License.

(c) (i)

Data availability. TRENDY v8 data were downloaded from trendy-v8@trendy.ex.ac.uk. OCO-2 MIPv9 fluxes were downloaded from https://gml.noaa.gov/ccgg/OCO2_v9mip/. GFED data were downloaded from https://www.globalfiredata.org/. GFAS data were downloaded from https://apps.ecmwf.int/datasets/. We downloaded version 10 of the ACOS OCO-2 lite files from the $\mathrm{CO}_{2}$ Virtual Science Data Environment (https://CO $\mathrm{CO}_{2}$.jpl.nasa.gov/). OCO-2 data were produced by the OCO-2 project at the Jet Propulsion Laboratory, California Institute of Technology, and obtained from the OCO-2 data archive maintained at the NASA Goddard Earth Science Data and Information Services Center. FluxSat data were downloaded from https://avdc.gsfc.nasa.gov/pub/tmp/FluxSat_GPP/. The GOSIF data product is available at http://data.globalecology.unh.edu/. ERA5-Land data are obtained from the Climate Data Store (https://cds.climate.copernicus.eu).

\section{Appendix A: Appendix 1}

We estimate seasonal variations in labile carbon by estimating a litterfall flux of carbon. Litterfall is assumed to be a fraction of NPP, following Randerson et al. (1996) (Fig. S15), and in steady state on annual timescales:

Litterfall $(t)=f_{\mathrm{NPP}}(t) \cdot \operatorname{NPP}(t) \cdot \int_{0}^{365} \frac{\mathrm{R}_{\mathrm{h}}(t)}{f_{\mathrm{NPP}}(t) \cdot \operatorname{NPP}(t)} d t$, figure

where $t$ is the day of the year and $f_{\mathrm{NPP}}$ is the frac NPP that is converted to litterfall. The seasonal variation in the labile carbon pool $\left(\Delta \mathrm{C}_{\text {pool }}\right)$ is defined as the difference in flux between litterfall and Rh:

$\Delta \mathrm{C}_{\text {pool }}(t)=\int_{0}^{t}\left(\right.$ Litterfall $\left.(t)-\mathrm{R}_{\mathrm{h}}(t)\right) d t$

455 Finally, we assume a fractional variation in the total carbon pool amount, $\gamma$, and calculate $\alpha(t)$ :

$\alpha(t)=\left(\frac{\mathrm{C}_{\text {pool }}(t)}{\max \left(\left|\mathrm{C}_{\text {pool }}(t)\right|\right)} \gamma+1\right) \alpha_{0}$,

where $\alpha_{0}$ is the mean carbon pool size, and is optimized in the regression in Sec. 3.3.

Author contributions. BB, JL, YY, AC, KWB, NCP, DC, and CEM conceived of the study. BB, JL, YY, AC, and SB designed the experiments. YY performed the soil carbon decomposition model runs. BB, SB and FC performed inversions for this study. BB performed the analysis and prepared the manuscript with contributions from all co-authors.

Competing interests. no competing interests are present

Acknowledgements. BB and JL were supported by the NASA OCO2/3 science team program NNH17ZDA001N-OCO2. AC, BB, JL and SB were also supported by the NASA OCO Science Team Grant \#80NSSC21K1068. CEM was supported by NASA's Arctic Boreal Vulnerability Experiment (ABoVE) under NNH18ZDA001N-TE. JX was supported by the National Science Foundation (NSF) (Macrosystem 
https://doi.org/10.5194/bg-2022-40

Preprint. Discussion started: 2 March 2022

(C) Author(s) 2022. CC BY 4.0 License.

(c) (1)

465 Biology \& NEON-Enabled Science program: DEB-2017870). MSJ acknowledges the internal funding from NASA's Earth Science Research and Analysis Program. SP acknowledges financial support of the NASA Academic Mission Services by Universities Space Research Association at NASA Ames Research Center. FC was funded by the Copernicus Atmosphere Monitoring Service, implemented by the European Centre for Medium-Range Weather Forecasts on behalf of the European Commission (grant no. CAMS73). The research carried out at the Jet Propulsion Laboratory, California Institute of Technology, was under a contract with the National Aeronautics and Space Administration.

470 Resources supporting this work were provided by the NASA High-End Computing (HEC) Program through the NASA Advanced Supercomputing (NAS) Division at Ames Research Center. FC was granted access to the HPC resources of TGCC under the allocation A0110102201 made by GENCI. ODIAC project is supported by Greenhouse Gas Observing SATellite (GOSAT) project, National Institute for Environmental Studies (NIES), Japan. (C2022. All rights reserved. California Institute of Technology, government sponsorship acknowledged. 
https://doi.org/10.5194/bg-2022-40

Preprint. Discussion started: 2 March 2022

(c) Author(s) 2022. CC BY 4.0 License.

(c) (i)

\section{References}

Arndt, K. A., Lipson, D. A., Hashemi, J., Oechel, W. C., and Zona, D.: Snow melt stimulates ecosystem respiration in Arctic ecosystems, Global Change Biology, 26, 5042-5051, 2020.

Basu, S., Guerlet, S., Butz, A., Houweling, S., Hasekamp, O., Aben, I., Krummel, P., Steele, P., Langenfelds, R., Torn, M., Biraud, S., Stephens, B., Andrews, A., and Worthy, D.: Global $\mathrm{CO}_{2}$ Fluxes Estimated from GOSAT Retrievals of Total Column $\mathrm{CO}_{2}$, Atmospheric Chemistry and Physics, 13, 8695-8717, https://doi.org/10.5194/acpd-13-4535-2013, 2013.

Basu, S., Baker, D. F., Chevallier, F., Patra, P. K., Liu, J., and Miller, J. B.: The impact of transport model differences on $\mathrm{CO}_{2}$ surface flux estimates from OCO-2 retrievals of column average $\mathrm{CO}_{2}$, Atmospheric Chemistry \& Physics, 18, 2018.

Bing, H., He, P., and Zhang, Y.: Cyclic freeze-thaw as a mechanism for water and salt migration in soil, Environmental Earth Sciences, 74, 675-681, 2015.

Björkman, M. P., Morgner, E., Cooper, E. J., Elberling, B., Klemedtsson, L., and Björk, R. G.: Winter carbon dioxide effluxes from Arctic ecosystems: An overview and comparison of methodologies, Global Biogeochemical Cycles, 24, 2010.

Byrne, B., Jones, D. B. A., Strong, K., Zeng, Z.-C., Deng, F., and Liu, J.: Sensitivity of $\mathrm{CO}_{2}$ Surface Flux Constraints to Observational Coverage, J. Geophys. Res.-Atmos, 112, 6672-6694, https://doi.org/10.1002/2016JD026164, 2017.

Byrne, B., Wunch, D., Jones, D., Strong, K., Deng, F., Baker, I., Köhler, P., Frankenberg, C., Joiner, J., Arora, V., et al.: Evaluating GPP and

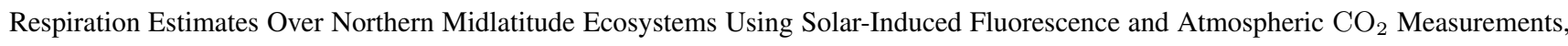
Journal of Geophysical Research: Biogeosciences, 123, 2976-2997, 2018.

Byrne, B., Liu, J., Bloom, A. A., Bowman, K. W., Butterfield, Z., Joiner, J., Keenan, T. F., Keppel-Aleks, G., Parazoo, N. C., and Yin, Y.: Contrasting regional carbon cycle responses to seasonal climate anomalies across the east-west divide of temperate North America, Global biogeochemical cycles, 34, e2020GB006 598, 2020a.

Byrne, B., Liu, J., Lee, M., Baker, I. T., Bowman, K. W., Deutscher, N. M., Feist, D. G., Griffith, D. W., Iraci, L. T., Kiel, M., Kimball, J., Miller, C. E., Morino, I., Parazoo, N. C., Petri, C., Roehl, C. M., Sha, M., Strong, K., Velazco, V. A., Wennberg, P. O., and Wunch, D.: Improved constraints on northern extratropical $\mathrm{CO}_{2}$ fluxes obtained by combining surface-based and space-based atmospheric $\mathrm{CO}_{2}$ measurements, Journal ofGeophysical Research: Atmospheres, 125, https://doi.org/10.1029/2019JD032029, 2020 b.

Chen, L., Aalto, J., and Luoto, M.: Significant shallow-depth soil warming over Russia during the past 40 years, Global and Planetary Change, 197, $103394,2021$.

Chevallier, F.: On the parallelization of atmospheric inversions of $\mathrm{CO}_{2}$ surface fluxes within a variational framework, Geoscientific Model Development, 6, 783-790, https://doi.org/10.5194/gmd-6-783-2013, 2013.

Chevallier, F., Fisher, M., Peylin, P., Serrar, S., Bousquet, P., Bréon, F.-M., Chédin, A., and Ciais, P.: Inferring $\mathrm{CO}_{2}$ sources and sinks from satellite observations: Method and application to TOVS data, Journal of Geophysical Research: Atmospheres, $110,2005$.

Chevallier, F., Ciais, P., Conway, T., Aalto, T., Anderson, B., Bousquet, P., Brunke, E., Ciattaglia, L., Esaki, Y., Fröhlich, M., et al.: CO 2 surface fluxes at grid point scale estimated from a global 21 year reanalysis of atmospheric measurements, Journal of Geophysical Research: Atmospheres, 115, 2010.

Commane, R., Lindaas, J., Benmergui, J., Luus, K. A., Chang, R. Y.-W., Daube, B. C., Euskirchen, E. S., Henderson, J. M., Karion, A., Miller, J. B., et al.: Carbon dioxide sources from Alaska driven by increasing early winter respiration from Arctic tundra, Proc. Natl. Acad. Sci., 114, 5361-5366, https://doi.org/10.1073/pnas.1618567114, 2017. 
https://doi.org/10.5194/bg-2022-40

Preprint. Discussion started: 2 March 2022

(c) Author(s) 2022. CC BY 4.0 License.

\section{(c) (i)}

Crisp, D., Pollock, H. R., Rosenberg, R., Chapsky, L., Lee, R. A., Oyafuso, F. A., Frankenberg, C., O’Dell, C. W., Bruegge, C. J., Doran, G. B., et al.: The on-orbit performance of the Orbiting Carbon Observatory-2 (OCO-2) instrument and its radiometrically calibrated products, Atmospheric Measurement Techniques, 10, 59-81, 2017.

Doughty, R., Xiao, X., Köhler, P., Frankenberg, C., Qin, Y., Wu, X., Ma, S., and Moore III, B.: Global-scale consistency of spaceborne vegetation indices, chlorophyll fluorescence, and photosynthesis, Journal of Geophysical Research: Biogeosciences, p. e2020JG006136, 2021.

Drotz, S. H., Sparrman, T., Nilsson, M. B., Schleucher, J., and Öquist, M. G.: Both catabolic and anabolic heterotrophic microbial activity proceed in frozen soils, Proceedings of the National Academy of Sciences, 107, 21 046-21 051, 2010.

Eldering, A., O’Dell, C. W., Wennberg, P. O., Crisp, D., Gunson, M. R., Viatte, C., Avis, C., Braverman, A., Castano, R., Chang, A., Chapsky, L., Cheng, C., Connor, B., Dang, L., Doran, G., Fisher, B., Frankenberg, C., Fu, D., Granat, R., Hobbs, J., Lee, R. A. M., Mandrake, L., McDuffie, J., Miller, C. E., Myers, V., Natraj, V., O’Brien, D., Osterman, G. B., Oyafuso, F., Payne, V. H., Pollock, H. R., Polonsky, I., Roehl, C. M., Rosenberg, R., Schwandner, F., Smyth, M., Tang, V., Taylor, T. E., To, C., Wunch, D., and Yoshimizu, J.: The Orbiting Carbon Observatory-2: first 18 months of science data products, Atmos. Meas. Tech., 10, 549-563, https://doi.org/10.5194/amt-10-549$2017,2017$.

Endsley, K. A., Kimball, J., and Reichle, R. H.: Soil respiration phenology improves modeled phase of terrestrial net ecosystem exchange in northern hemisphere, Earth and Space Science Open Archive, p. 31, https://doi.org/10.1002/essoar.10507940.1, 2021.

Euskirchen, E., Bret-Harte, M., Shaver, G., Edgar, C., and Romanovsky, V.: Long-term release of carbon dioxide from arctic tundra ecosystems in Alaska, Ecosystems, 20, 960-974, 2017.

Eyring, V., Bony, S., Meehl, G. A., Senior, C. A., Stevens, B., Stouffer, R. J., and Taylor, K. E.: Overview of the Coupled Model Intercomparison Project Phase 6 (CMIP6) experimental design and organization, Geoscientific Model Development, 9, 1937-1958, https://doi.org/10.5194/gmd-9-1937-2016, 2016.

Friedlingstein, P., Jones, M. W., O’Sullivan, M., Andrew, R. M., Hauck, J., Peters, G. P., Peters, W., Pongratz, J., Sitch, S., Le Quéré, C., Bakker, D. C. E., Canadell, J. G., Ciais, P., Jackson, R. B., Anthoni, P., Barbero, L., Bastos, A., Bastrikov, V., Becker, M., Bopp, L., Buitenhuis, E., Chandra, N., Chevallier, F., Chini, L. P., Currie, K. I., Feely, R. A., Gehlen, M., Gilfillan, D., Gkritzalis, T., Goll, D. S., Gruber, N., Gutekunst, S., Harris, I., Haverd, V., Houghton, R. A., Hurtt, G., Ilyina, T., Jain, A. K., Joetzjer, E., Kaplan, J. O., Kato, E., Klein Goldewijk, K., Korsbakken, J. I., Landschützer, P., Lauvset, S. K., Lefèvre, N., Lenton, A., Lienert, S., Lombardozzi, D., Marland, G., McGuire, P. C., Melton, J. R., Metzl, N., Munro, D. R., Nabel, J. E. M. S., Nakaoka, S.-I., Neill, C., Omar, A. M., Ono, T., Peregon, A., Pierrot, D., Poulter, B., Rehder, G., Resplandy, L., Robertson, E., Rödenbeck, C., Séférian, R., Schwinger, J., Smith, N., Tans, P. P., Tian, H., Tilbrook, B., Tubiello, F. N., van der Werf, G. R., Wiltshire, A. J., and Zaehle, S.: Global Carbon Budget 2019, Earth System Science Data, 11, 1783-1838, https://doi.org/10.5194/essd-11-1783-2019, 2019.

Gelaro, R., McCarty, W., Suárez, M. J., Todling, R., Molod, A., Takacs, L., Randles, C. A., Darmenov, A., Bosilovich, M. G., Reichle, R., et al.: The modern-era retrospective analysis for research and applications, version 2 (MERRA-2), J. Climate, 30, 5419-5454, 2017.

Giglio, L., Randerson, J. T., and Van Der Werf, G. R.: Analysis of daily, monthly, and annual burned area using the fourth-generation global fire emissions database (GFED4), Journal of Geophysical Research: Biogeosciences, 118, 317-328, 2013.

Henze, D. K., Hakami, A., and Seinfeld, J. H.: Development of the adjoint of GEOS-Chem, Atmos. Chem. Phys., 7, $2413-2433,2007$.

Hinkel, K., Paetzold, F., Nelson, F., and Bockheim, J.: Patterns of soil temperature and moisture in the active layer and upper permafrost at Barrow, Alaska: 1993-1999, Global and Planetary Change, 29, 293-309, 2001. 
https://doi.org/10.5194/bg-2022-40

Preprint. Discussion started: 2 March 2022

(c) Author(s) 2022. CC BY 4.0 License.

\section{(c) (i)}

Hu, L., Montzka, S. A., Kaushik, A., Andrews, A. E., Sweeney, C., Miller, J., Baker, I. T., Denning, S., Campbell, E., Shiga, Y. P., et al.: COS-derived GPP relationships with temperature and light help explain high-latitude atmospheric $\mathrm{CO}_{2}$ seasonal cycle amplification, Proceedings of the National Academy of Sciences, 118, 2021.

Jacobs, N., Simpson, W. R., Wunch, D., O’Dell, C. W., Osterman, G. B., Hase, F., Blumenstock, T., Tu, Q., Frey, M., Dubey, M. K., Parker, H. A., Kivi, R., and Heikkinen, P.: Quality controls, bias, and seasonality of $\mathrm{CO}_{2}$ columns in the boreal forest with Orbiting Carbon Observatory-2, Total Carbon Column Observing Network, and EM27/SUN measurements, Atmospheric Measurement Techniques, 13, 5033-5063, https://doi.org/10.5194/amt-13-5033-2020, 2020.

Jacobs, N., Simpson, W. R., Graham, K. A., Holmes, C., Hase, F., Blumenstock, T., Tu, Q., Frey, M., Dubey, M. K., Parker, H. A., Wunch, D., Kivi, R., Heikkinen, P., Notholt, J., Petri, C., and Warneke, T.: Spatial distributions of $\mathrm{X}_{\mathrm{CO}_{2}}$ seasonal cycle amplitude and phase over northern high-latitude regions, Atmospheric Chemistry and Physics, 21, 16 661-16687, https://doi.org/10.5194/acp-21-16661-2021, 2021.

Jeong, S.-J., Bloom, A. A., Schimel, D., Sweeney, C., Parazoo, N. C., Medvigy, D., Schaepman-Strub, G., Zheng, C., Schwalm, C. R., Huntzinger, D. N., et al.: Accelerating rates of Arctic carbon cycling revealed by long-term atmospheric $\mathrm{CO}_{2}$ measurements, Science advances, 4, eaao1167, 2018.

Joiner, J. and Yoshida, Y.: Satellite-based reflectances capture large fraction of variability in global gross primary production (GPP) at weekly time scales, Agricultural and Forest Meteorology, 291, 108 092, https://doi.org/https://doi.org/10.1016/j.agrformet.2020.108092, 2020.

Jones, C. D., Arora, V., Friedlingstein, P., Bopp, L., Brovkin, V., Dunne, J., Graven, H., Hoffman, F., Ilyina, T., John, J. G., Jung, M., Kawamiya, M., Koven, C., Pongratz, J., Raddatz, T., Randerson, J. T., and Zaehle, S.: C4MIP - The Coupled ClimateCarbon Cycle Model Intercomparison Project: experimental protocol for CMIP6, Geoscientific Model Development, 9, 2853-2880, https://doi.org/10.5194/gmd-9-2853-2016, 2016.

Jung, M., Schwalm, C., Migliavacca, M., Walther, S., Camps-Valls, G., Koirala, S., Anthoni, P., Besnard, S., Bodesheim, P., Carvalhais, N., Chevallier, F., Gans, F., Goll, D. S., Haverd, V., Köhler, P., Ichii, K., Jain, A. K., Liu, J., Lombardozzi, D., Nabel, J. E. M. S., Nelson, J. A., O’Sullivan, M., Pallandt, M., Papale, D., Peters, W., Pongratz, J., Rödenbeck, C., Sitch, S., Tramontana, G., Walker, A., Weber, U., and Reichstein, M.: Scaling carbon fluxes from eddy covariance sites to globe: synthesis and evaluation of the FLUXCOM approach, Biogeosciences, 17, 1343-1365, https://doi.org/10.5194/bg-17-1343-2020, 2020.

Keenan, T. F., Migliavacca, M., Papale, D., Baldocchi, D., Reichstein, M., Torn, M., and Wutzler, T.: Widespread inhibition of daytime ecosystem respiration, Nature ecology \& evolution, 3, 407-415, 2019.

Koven, C. D., Riley, W. J., Subin, Z. M., Tang, J. Y., Torn, M. S., Collins, W. D., Bonan, G. B., Lawrence, D. M., and Swenson, S. C.: The effect of vertically resolved soil biogeochemistry and alternate soil $\mathrm{C}$ and $\mathrm{N}$ models on $\mathrm{C}$ dynamics of CLM4, Biogeosciences, 10, 7109-7131, https://doi.org/10.5194/bg-10-7109-2013, 2013.

Li, X. and Xiao, J.: Mapping photosynthesis solely from solar-induced chlorophyll fluorescence: A global, fine-resolution dataset of gross primary production derived from OCO-2, Remote Sensing, 11, 2563, 2019.

Lin, X., Rogers, B. M., Sweeney, C., Chevallier, F., Arshinov, M., Dlugokencky, E., Machida, T., Sasakawa, M., Tans, P., and Keppel-Aleks,

G.: Siberian and temperate ecosystems shape Northern Hemisphere atmospheric $\mathrm{CO}_{2}$ seasonal amplification, Proceedings of the National Academy of Sciences, 117, 21 079-21 087, 2020.

Liu, J., Bowman, K. W., Lee, M., Henze, D. K., Bousserez, N., Brix, H., Collatz, G. J., Menemenlis, D., Ott, L., Pawson, S., et al.: Carbon monitoring system flux estimation and attribution: impact of ACOS-GOSAT $\mathrm{X}_{\mathrm{CO}_{2}}$ sampling on the inference of terrestrial biospheric sources and sinks, Tellus B, 66, 22 486, https://doi.org/10.3402/tellusb.v66.22486, 2014. 
https://doi.org/10.5194/bg-2022-40

Preprint. Discussion started: 2 March 2022

(c) Author(s) 2022. CC BY 4.0 License.

(c) (i)

Liu, J., Bowman, K. W., Schimel, D. S., Parazoo, N. C., Jiang, Z., Lee, M., Bloom, A. A., Wunch, D., Frankenberg, C., Sun, Y., O’Dell, C. W., Gurney, K. R., Menemenlis, D., Gierach, M., Crisp, D., and Eldering, A.: Contrasting carbon cycle responses of the tropical continents to the 2015-2016 El Niño, Science, 358, https://doi.org/10.1126/science.aam5690, 2017.

Liu, J., Wennberg, P. O., Parazoo, N. C., Yin, Y., and Frankenberg, C.: Observational constraints on the response of high-latitude northern forests to warming, AGU Advances, 1, e2020AV000 228, 2020.

Masarie, K., Peters, W., Jacobson, A., and Tans, P.: ObsPack: a framework for the preparation, delivery, and attribution of atmospheric greenhouse gas measurements, Earth Syst. Sci. Data, 6, 375-384, 2014.

Mastepanov, M., Sigsgaard, C., Tagesson, T., Ström, L., Tamstorf, M. P., Lund, M., and Christensen, T. R.: Revisiting factors controlling methane emissions from high-Arctic tundra, Biogeosciences, 10, 5139-5158, https://doi.org/10.5194/bg-10-5139-2013, 2013.

McGuire, A. D., Lawrence, D. M., Koven, C., Clein, J. S., Burke, E., Chen, G., Jafarov, E., MacDougall, A. H., Marchenko, S., Nicolsky, D., et al.: Dependence of the evolution of carbon dynamics in the northern permafrost region on the trajectory of climate change, Proceedings of the National Academy of Sciences, 115, 3882-3887, 2018.

McMahon, S. K., Wallenstein, M. D., and Schimel, J. P.: Microbial growth in Arctic tundra soil at -2 C, Environmental Microbiology Reports, 1, 162-166, 2009.

Meirink, J. F., Bergamaschi, P., and Krol, M. C.: Four-Dimensional Variational Data Assimilation for Inverse Modelling of Atmospheric Methane Emissions: Method and Comparison with Synthesis Inversion, Atmospheric Chemistry and Physics, 8, 6341-6353, https://doi.org/10.5194/acp-8-6341-2008, 2008.

Mendonca, J., Nassar, R., O’Dell, C. W., Kivi, R., Morino, I., Notholt, J., Petri, C., Strong, K., and Wunch, D.: Assessing the feasibility of using a neural network to filter Orbiting Carbon Observatory 2 (OCO-2) retrievals at northern high latitudes, Atmospheric Measurement Techniques, 14, 7511-7524, https://doi.org/10.5194/amt-14-7511-2021, 2021.

Mikkonen, A., Lindqvist, H., Peltoniemi, J., and Tamminen, J.: Satellite-based remote sensing of carbon dioxide over snow-covered surfaces, in: EGU General Assembly Conference Abstracts, EGU General Assembly Conference Abstracts, pp. EGU21-8207, 2021.

Miner, K. R., Turetsky, M. R., Malina, E., Bartsch, A., Tamminen, J., McGuire, A. D., Fix, A., Sweeney, C., Elder, C. D., and Miller, C. E.: Permafrost carbon emissions in a changing Arctic, Nature Reviews Earth \& Environment, 3, 55-67, 2022.

Munoz Sabater, J.: Copernicus Climate Change Service (C3S) Climate Data Store (CDS), https://doi.org/10.24381/cds.68d2bb30, 2020-0811, 2019.

Natali, S. M., Watts, J. D., Rogers, B. M., Potter, S., Ludwig, S. M., Selbmann, A.-K., Sullivan, P. F., Abbott, B. W., Arndt, K. A., Birch, L., et al.: Large loss of $\mathrm{CO}_{2}$ in winter observed across the northern permafrost region, Nature Climate Change, 9, 852-857, 2019.

Obu, J., Westermann, S., Kääb, A., and Bartsch, A.: Ground Temperature Map, 2000-2016, Northern Hemisphere Permafrost, https://doi.org/10.1594/PANGAEA.888600, 2018.

Obu, J., Westermann, S., Bartsch, A., Berdnikov, N., Christiansen, H. H., Dashtseren, A., Delaloye, R., Elberling, B., Etzelmüller, B., Kholodov, A., Khomutov, A., Kääb, A., Leibman, M. O., Lewkowicz, A. G., Panda, S. K., Romanovsky, V., Way, R. G., WestergaardNielsen, A., Wu, T., Yamkhin, J., and Zou, D.: Northern Hemisphere permafrost map based on TTOP modelling for 2000-2016 at 1 km² scale, Earth-Science Reviews, 193, 299-316, https://doi.org/https://doi.org/10.1016/j.earscirev.2019.04.023, 2019.

Oda, T. and Maksyutov, S.: A very high-resolution $(1 \mathrm{~km} \times 1 \mathrm{~km})$ global fossil fuel CO 2 emission inventory derived using a point source database and satellite observations of nighttime lights, Atmos. Chem. Phys., 11, 543-556, 2011. 
https://doi.org/10.5194/bg-2022-40

Preprint. Discussion started: 2 March 2022

(c) Author(s) 2022. CC BY 4.0 License.

Oda, T., Maksyutov, S., and Andres, R. J.: The Open-source Data Inventory for Anthropogenic $\mathrm{CO}_{2}$, version 2016 (ODIAC2016): a global monthly fossil fuel $\mathrm{CO}_{2}$ gridded emissions data product for tracer transport simulations and surface flux inversions, Earth Syst. Sci. Data, 10, 87-107, https://doi.org/10.5194/essd-10-87-2018, 2018.

Oikawa, P., Sturtevant, C., Knox, S., Verfaillie, J., Huang, Y., and Baldocchi, D.: Revisiting the partitioning of net ecosystem exchange of $\mathrm{CO}_{2}$ into photosynthesis and respiration with simultaneous flux measurements of ${ }^{13} \mathrm{CO}_{2}$ and $\mathrm{CO}_{2}$, soil respiration and a biophysical model, CANVEG, Agricultural and Forest Meteorology, 234, 149-163, 2017.

Outcalt, S. I., Nelson, F. E., and Hinkel, K. M.: The zero-curtain effect: Heat and mass transfer across an isothermal region in freezing soil, Water Resources Research, 26, 1509-1516, 1990.

Overland, J., Hanna, E., Hanssen-Bauer, I., Kim, S.-J., Walsh, J., Wang, M., Bhatt, U., Thoman, R., et al.: Surface air temperature, Arctic report card, 2018.

Panikov, N., Flanagan, P., Oechel, W., Mastepanov, M., and Christensen, T.: Microbial activity in soils frozen to below -39 C, Soil Biology and Biochemistry, 38, 785-794, 2006.

Parazoo, N. C., Arneth, A., Pugh, T. A., Smith, B., Steiner, N., Luus, K., Commane, R., Benmergui, J., Stofferahn, E., Liu, J., et al.: Spring photosynthetic onset and net $\mathrm{CO}_{2}$ uptake in Alaska triggered by landscape thawing, Global change biology, 24, 3416-3435, 2018a.

Parazoo, N. C., Koven, C. D., Lawrence, D. M., Romanovsky, V., and Miller, C. E.: Detecting the permafrost carbon feedback: talik formation and increased cold-season respiration as precursors

to sink-to-source transitions, The Cryosphere, 12, 123-144, https://doi.org/10.5194/tc-12-123-2018, $2018 \mathrm{~b}$.

Park, T., Ganguly, S., Tømmervik, H., Euskirchen, E. S., Høgda, K.-A., Karlsen, S. R., Brovkin, V., Nemani, R. R., and Myneni, R. B.: Changes in growing season duration and productivity of northern vegetation inferred from long-term remote sensing data, Environmental Research Letters, 11, $084001,2016$.

Pastorello, G., Trotta, C., Canfora, E., Chu, H., Christianson, D., Cheah, Y.-W., Poindexter, C., Chen, J., Elbashandy, A., Humphrey, M., Isaac, P., Polidori, D., Ribeca, A., van Ingen, C., Zhang, L., Amiro, B., Ammann, C., Arain, M. A., Ard Ãף, J., Arkebauer, T., Arndt, S. K., Arriga, N., Aubinet, M., Aurela, M., Baldocchi, D., Barr, A., Beamesderfer, E., Marchesini, L. B., Bergeron, O., Beringer, J., Bernhofer, C., Berveiller, D., Billesbach, D., Black, T. A., Blanken, P. D., Bohrer, G., Boike, J., Bolstad, P. V., Bonal, D., Bonnefond, J.-M., Bowling, D. R., Bracho, R., Brodeur, J., BrÃ¹/4mmer, C., Buchmann, N., Burban, B., Burns, S. P., Buysse, P., Cale, P., Cavagna, M., Cellier, P., Chen, S., Chini, I., Christensen, T. R., Cleverly, J., Collalti, A., Consalvo, C., Cook, B. D., Cook, D., Coursolle, C., Cremonese, E., Curtis, P. S., Dât ${ }^{\mathrm{TM}}$ Andrea, E., da Rocha, H., Dai, X., Davis, K. J., De Cinti, B., de Grandcourt, A., De Ligne, A., De Oliveira, R. C., Delpierre, N., Desai, A. R., Di Bella, C. M., di Tommasi, P., Dolman, H., Domingo, F., Dong, G., Dore, S., Duce, P., Dufrãane, E., Dunn, A., Du $\AA_{j}$ ek, J., Eamus, D., Eichelmann, U., ElKhidir, H. A. M., Eugster, W., Ewenz, C. M., Ewers, B., Famulari, D., Fares, S., Feigenwinter,

I., Feitz, A., Fensholt, R., Filippa, G., Fischer, M., Frank, J., Galvagno, M., Gharun, M., Gianelle, D., Gielen, B., Gioli, B., Gitelson, A., Goded, I., Goeckede, M., Goldstein, A. H., Gough, C. M., Goulden, M. L., Graf, A., Griebel, A., Gruening, C., Grã̃²nwald, T., Hammerle, A., Han, S., Han, X., Hansen, B. U., Hanson, C., Hatakka, J., He, Y., Hehn, M., Heinesch, B., Hinko-Najera, N., HÃ đrtnagl, L., Hutley, L., Ibrom, A., Ikawa, H., Jackowicz-Korczynski, M., JanouÅ , , D., Jans, W., Jassal, R., Jiang, S., Kato, T., Khomik, M., Klatt, J., Knohl, A., Knox, S., Kobayashi, H., Koerber, G., Kolle, O., Kosugi, Y., Kotani, A., Kowalski, A., Kruijt, B., Kurbatova, J., Kutsch, W. L., Kwon, H., Launiainen, S., Laurila, T., Law, B., Leuning, R., Li, Y., Liddell, M., Limousin, J.-M., Lion, M., Liska, A. J., Lohila, A., LÃ ${ }^{3}$ pez-Ballesteros, A., LÃ ${ }^{3}$ pez-Blanco, E., Loubet, B., Loustau, D., Lucas-Moffat, A., LÃªers, J., Ma, S., Macfarlane, C., Magliulo, V., Maier, R., Mammarella, I., Manca, G., Marcolla, B., Margolis, H. A., Marras, S., Massman, W., Mastepanov, M., Matamala, R., Matthes, J. H., Mazzenga, F., McCaughey, H., McHugh, I., McMillan, A. M. S., Merbold, L., Meyer, W., Meyers, T., Miller, S. D., Minerbi, S., 
https://doi.org/10.5194/bg-2022-40

Preprint. Discussion started: 2 March 2022

(c) Author(s) 2022. CC BY 4.0 License.

\section{(c) (i)}

Moderow, U., Monson, R. K., Montagnani, L., Moore, C. E., Moors, E., Moreaux, V., Moureaux, C., Munger, J. W., Nakai, T., Neirynck,

J., Nesic, Z., Nicolini, G., Noormets, A., Northwood, M., Nosetto, M., Nouvellon, Y., Novick, K., Oechel, W., Olesen, J. E., Ourcival, J.-M., Papuga, S. A., Parmentier, F.-J., Paul-Limoges, E., Pavelka, M., Peichl, M., Pendall, E., Phillips, R. P., Pilegaard, K., Pirk, N., Posse, G., Powell, T., Prasse, H., Prober, S. M., Rambal, S., Rannik, U., Raz-Yaseef, N., Reed, D., de Dios, V. R., Restrepo-Coupe, N., Reverter, B. R., Roland, M., Sabbatini, S., Sachs, T., Saleska, S. R., SÃ nchez-CaÃ \pm ete, E. P., Sanchez-Mejia, Z. M., Schmid, H. P., Schmidt, M., Schneider, K., Schrader, F., Schroder, I., Scott, R. L., Sedlã $j k$, P., Serrano-OrtÃz, P., Shao, C., Shi, P., Shironya, I., Siebicke, L., Å igut, L., Silberstein, R., Sirca, C., Spano, D., Steinbrecher, R., Stevens, R. M., Sturtevant, C., Suyker, A., Tagesson, T., Takanashi, S., Tang, Y., Tapper, N., Thom, J., Tiedemann, F., Tomassucci, M., Tuovinen, J.-P., Urbanski, S., Valentini, R., van der Molen, M., van Gorsel, E., van Huissteden, K., Varlagin, A., Verfaillie, J., Vesala, T., Vincke, C., Vitale, D., Vygodskaya, N., Walker, J. P., Walter-Shea, E., Wang, H., Weber, R., Westermann, S., Wille, C., Wofsy, S., Wohlfahrt, G., Wolf, S., Woodgate, W., Li, Y., Zampedri, R., Zhang, J., Zhou, G., Zona, D., Agarwal, D., Biraud, S., Torn, M., and Papale, D.: The FLUXNET2015 dataset and the ONEFlux processing pipeline for eddy covariance data, Scientific Data, 7, 225, https://doi.org/10.1038/s41597-020-0534-3, 2020.

Peiro, H., Crowell, S., Schuh, A., Baker, D. F., O’Dell, C., Jacobson, A. R., Chevallier, F., Liu, J., Eldering, A., Crisp, D., Deng, F., Weir, B., Basu, S., Johnson, M. S., Philip, S., and Baker, I.: Four years of global carbon cycle observed from OCO-2 version 9 and in situ data, and comparison to OCO-2 v7, Atmospheric Chemistry and Physics Discussions, 2021, 1-50, https://doi.org/10.5194/acp-2021-373, 2021.

Peylin, P., Bousquet, P., Le Quéré, C., Sitch, S., Friedlingstein, P., McKinley, G., Gruber, N., Rayner, P., and Ciais, P.: Multiple constraints on regional CO2 flux variations over land and oceans, Global Biogeochemical Cycles, 19, 2005.

Pirk, N., Santos, T., Gustafson, C., Johansson, A. J., Tufvesson, F., Parmentier, F.-J. W., Mastepanov, M., and Christensen, T. R.: Methane emission bursts from permafrost environments during autumn freeze-in: New insights from ground-penetrating radar, Geophysical Research Letters, 42, 6732-6738, 2015.

Randerson, J., Chen, Y., Van Der Werf, G., Rogers, B., and Morton, D.: Global burned area and biomass burning emissions from small fires, Journal of Geophysical Research: Biogeosciences, 117, 2012.

Randerson, J. T., Thompson, M. V., Malmstrom, C. M., Field, C. B., and Fung, I. Y.: Substrate limitations for heterotrophs: Implications for models that estimate the seasonal cycle of atmospheric $\mathrm{CO}_{2}$, Global Biogeochem. Cy., 10, 585-602, https://doi.org/10.1029/96GB01981, 1996.

Raz-Yaseef, N., Torn, M. S., Wu, Y., Billesbach, D. P., Liljedahl, A. K., Kneafsey, T. J., Romanovsky, V. E., Cook, D. R., and Wullschleger, S. D.: Large $\mathrm{CO}_{2}$ and $\mathrm{CH}_{4}$ emissions from polygonal tundra during spring thaw in northern Alaska, Geophysical Research Letters, 44, 504-513, 2017.

Reichle, R. H., Koster, R. D., De Lannoy, G. J., Forman, B. A., Liu, Q., Mahanama, S. P., and Touré, A.: Assessment and enhancement of MERRA land surface hydrology estimates, J. Climate, 24, 6322-6338, 2011.

Reichle, R. H., Draper, C. S., Liu, Q., Girotto, M., Mahanama, S. P., Koster, R. D., and De Lannoy, G. J.: Assessment of MERRA-2 land surface hydrology estimates, J. Climate, 30, 2937-2960, 2017.

Remaud, M., Chevallier, F., Cozic, A., Lin, X., and Bousquet, P.: On the impact of recent developments of the LMDz atmospheric general circulation model on the simulation of $\mathrm{CO}_{2}$ transport, Geoscientific Model Development, 11, 4489-4513, https://doi.org/10.5194/gmd11-4489-2018, 2018.

Rivkina, E., Friedmann, E., McKay, C., and Gilichinsky, D.: Metabolic activity of permafrost bacteria below the freezing point, Applied and Environmental Microbiology, 66, 3230-3233, 2000. 
https://doi.org/10.5194/bg-2022-40

Preprint. Discussion started: 2 March 2022

(c) Author(s) 2022. CC BY 4.0 License.

(c) (i)

Rogers, A., Serbin, S. P., Ely, K. S., Sloan, V. L., and Wullschleger, S. D.: Terrestrial biosphere models underestimate photosynthetic capacity and CO2 assimilation in the Arctic, New Phytologist, 216, 1090-1103, 2017.

Rogers, A., Serbin, S. P., Ely, K. S., and Wullschleger, S. D.: Terrestrial biosphere models may overestimate Arctic CO 2 assimilation if they do not account for decreased quantum yield and convexity at low temperature, New Phytologist, 223, 167-179, 2019.

Romanovsky, V. E. and Osterkamp, T.: Effects of unfrozen water on heat and mass transport processes in the active layer and permafrost, Permafrost and Periglacial Processes, 11, 219-239, 2000.

Sasakawa, M., Shimoyama, K., Machida, T., Tsuda, N., Suto, H., Arshinov, M., Davydov, D., Fofonov, A., Krasnov, O., Saeki, T., et al.: Continuous measurements of methane from a tower network over Siberia, Tellus B, 62, 403-416, https://doi.org/10.1111/j.16000889.2010.00494.x, 2010.

Sasakawa, M., Machida, T., Tsuda, N., Arshinov, M., Davydov, D., Fofonov, A., and Krasnov, O.: Aircraft and tower measurements of CO 2 concentration in the planetary boundary layer and the lower free troposphere over southern taiga in West Siberia: Long-term records from 2002 to 2011, J. Geophys. Res.-Atmos., 118, 9489-9498, https://doi.org/10.1002/jgrd.50755, 2013.

Schaaf, C. B., Gao, F., Strahler, A. H., Lucht, W., Li, X., Tsang, T., Strugnell, N. C., Zhang, X., Jin, Y., Muller, J.-P., et al.: First operational BRDF, albedo nadir reflectance products from MODIS, Remote sensing of Environment, 83, 135-148, 2002.

Schaefer, K. and Jafarov, E.: A parameterization of respiration in frozen soils based on substrate availability, Biogeosciences, 13, 1991-2001, https://doi.org/10.5194/bg-13-1991-2016, 2016.

Schuh, A. E., Jacobson, A. R., Basu, S., Weir, B., Baker, D., Bowman, K., Chevallier, F., Crowell, S., Davis, K. J., Deng, F., et al.: Quantifying the impact of atmospheric transport uncertainty on $\mathrm{CO}_{2}$ surface flux estimates, Global Biogeochem. Cy., 33, 484-500, 2019.

Schuldt, K., Mund, J., Luijkx, I. T., Jacobson, A. R., Aalto, T., Abshire, J. B., Aikin, K., Andrews, A., Aoki, S., Apadula, F., Baier, B., Bakwin, P., Bartyzel, J., Bentz, G., Bergamaschi, P., Beyersdorf, A., Biermann, T., Biraud, S. C., Bowling, D., Brailsford, G., Chen, G., Chen, H., Chmura, L., Clark, S., Climadat, S., Colomb, A., Commane, R., and van den Bulk, P.: Multi-laboratory compilation of atmospheric carbon dioxide data for the period 1957-2019; obspack_co2_1_GLOBALVIEWplus_v6.0_2020-09-11; NOAA Earth System Research Laboratory, Global Monitoring Laboratory, https://doi.org/10.25925/20200903, 2020.

Schuur, E. A., McGuire, A. D., Schädel, C., Grosse, G., Harden, J., Hayes, D. J., Hugelius, G., Koven, C. D., Kuhry, P., Lawrence, D. M., et al.: Climate change and the permafrost carbon feedback, Nature, 520, 171, 2015.

Seiler, C., Melton, J. R., Arora, V., Sitch, S., Friedlingstein, P., Arneth, A., Goll, D. S., Jain, A., Joetzjer, E., Lienert, S., and et al.: Are terrestrial biosphere models fit for simulating the global land carbon sink?, Earth and Space Science Open Archive, p. 48, https://doi.org/10.1002/essoar.10508892.1, 2021.

Sitch, S., Friedlingstein, P., Gruber, N., Jones, S. D., Murray-Tortarolo, G., Ahlström, A., Doney, S. C., Graven, H., Heinze, C., Huntingford, C., Levis, S., Levy, P. E., Lomas, M., Poulter, B., Viovy, N., Zaehle, S., Zeng, N., Arneth, A., Bonan, G., Bopp, L., Canadell, J. G., Chevallier, F., Ciais, P., Ellis, R., Gloor, M., Peylin, P., Piao, S. L., Le Quéré, C., Smith, B., Zhu, Z., and Myneni, R.: Recent trends and drivers of regional sources and sinks of carbon dioxide, Biogeosciences, 12, 653-679, https://doi.org/10.5194/bg-12-653-2015, 2015.

Turetsky, M. R., Abbott, B. W., Jones, M. C., Anthony, K. W., Olefeldt, D., Schuur, E. A., Koven, C., McGuire, A. D., Grosse, G., Kuhry, P., et al.: Permafrost collapse is accelerating carbon release, 2019.

730 Turetsky, M. R., Abbott, B. W., Jones, M. C., Anthony, K. W., Olefeldt, D., Schuur, E. A., Grosse, G., Kuhry, P., Hugelius, G., Koven, C., et al.: Carbon release through abrupt permafrost thaw, Nature Geoscience, 13, 138-143, 2020. 
https://doi.org/10.5194/bg-2022-40

Preprint. Discussion started: 2 March 2022

(c) Author(s) 2022. CC BY 4.0 License.

(c) (i)

van der Werf, G. R., Randerson, J. T., Giglio, L., van Leeuwen, T. T., Chen, Y., Rogers, B. M., Mu, M., van Marle, M. J. E., Morton, D. C.,

Collatz, G. J., Yokelson, R. J., and Kasibhatla, P. S.: Global fire emissions estimates during 1997-2016, Earth Syst. Sci. Data, 9, 697-720, https://doi.org/10.5194/essd-9-697-2017, 2017.

Veraverbeke, S., Rogers, B. M., Goulden, M. L., Jandt, R. R., Miller, C. E., Wiggins, E. B., and Randerson, J. T.: Lightning as a major driver of recent large fire years in North American boreal forests, Nature Climate Change, 7, 529, 2017.

Veraverbeke, S., Delcourt, C. J., Kukavskaya, E., Mack, M., Walker, X., Hessilt, T., Rogers, B., and Scholten, R. C.: Direct and longer-term carbon emissions from arctic-boreal fires: a short review of recent advances, Current Opinion in Environmental Science \& Health, p. $100277,2021$.

Wang, C., Chen, J., Wu, J., Tang, Y., Shi, P., Black, T. A., and Zhu, K.: A snow-free vegetation index for improved monitoring of vegetation spring green-up date in deciduous ecosystems, Remote sensing of environment, 196, 1-12, 2017.

Wehr, R., Munger, J., McManus, J., Nelson, D., Zahniser, M., Davidson, E., Wofsy, S., and Saleska, S.: Seasonality of temperate forest photosynthesis and daytime respiration, Nature, 534, 680, 2016.

Weir, B., Crisp, D., O’Dell, C. W., Basu, S., Chatterjee, A., Kolassa, J., Oda, T., Pawson, S., Poulter, B., Zhang, Z., Ciais, P., Davis, S. J., Liu, Z., and Ott, L. E.: Regional Impacts of COVID-19 on Carbon Dioxide Detected Worldwide from Space, Science Advances, 7, eabf9415, https://doi.org/10.1126/sciadv.abf9415, 2021.

Wilkman, E., Zona, D., Arndt, K., Gioli, B., Nakamoto, K., Lipson, D. A., and Oechel, W. C.: Ecosystem scale implication of soil CO 2 concentration dynamics during soil freezing in Alaskan Arctic tundra ecosystems, Journal of Geophysical Research: Biogeosciences, 126, e2020JG005 724, 2021.

Xiao, X., Zhang, Q., Braswell, B., Urbanski, S., Boles, S., Wofsy, S., Moore III, B., and Ojima, D.: Modeling gross primary production of temperate deciduous broadleaf forest using satellite images and climate data, Remote sensing of environment, 91, 256-270, 2004.

Yi, Y., Kimball, J. S., Rawlins, M. A., Moghaddam, M., and Euskirchen, E. S.: The role of snow cover affecting boreal-arctic soil freeze-thaw and carbon dynamics, Biogeosciences, 12, 5811-5829, https://doi.org/10.5194/bg-12-5811-2015, 2015.

Yi, Y., Kimball, J. S., Watts, J. D., Natali, S. M., Zona, D., Liu, J., Ueyama, M., Kobayashi, H., Oechel, W., and Miller, C. E.: Investigating the sensitivity of soil heterotrophic respiration to recent snow cover changes in Alaska using a satellite-based permafrost carbon model, Biogeosciences, 17, 5861-5882, https://doi.org/10.5194/bg-17-5861-2020, 2020.

Zhang, X.: Reconstruction of a complete global time series of daily vegetation index trajectory from long-term AVHRR data, Remote Sensing of Environment, 156, 457-472, 2015.

Zhang, Y., Xiao, X., Wu, X., Zhou, S., Zhang, G., Qin, Y., and Dong, J.: A global moderate resolution dataset of gross primary production of vegetation for 2000-2016, Scientific data, 4, 1-13, 2017.

Zimov, S., Semiletov, I., Daviodov, S., Voropaev, Y. V., Prosyannikov, S., Wong, C., and Chan, Y.-H.: Wintertime $\mathrm{CO}_{2}$ Emission from Soils of Northeastern Siberia, Arctic, pp. 197-204, 1993.

Zona, D., Gioli, B., Commane, R., Lindaas, J., Wofsy, S. C., Miller, C. E., Dinardo, S. J., Dengel, S., Sweeney, C., Karion, A., et al.: Cold season emissions dominate the Arctic tundra methane budget, Proceedings of the National Academy of Sciences, 113, 40-45, 2016. 